\title{
Af Fred. Fischers Dagbog 1864.
}

Ved Fr. Skrubbeltrang.

Hvis ikke den kendte Samling Biografier af førende Sønderjyder, der under Titlen "Haabets Mænd" udkom efter Verdenskrigen, naturligt havde begrænset sig til Mænd, hvis egentlige Livsgerning faldt efter 1864, maatte man med Føje savne Fr. Fischers Ansigt. Den gamle Aabenraaredaktør var gennem alle sit Livs Kampe og Genvordigheder en ukuelig Haabets Mand; Lyssynet svandt end ikke i Ulykkesaaret.

Fr. Fischers Indsats i det nationale og kulturelle Arbejde er ikke glemt - nylig rejstes hans Mindesten i "Folkehjem"s Have i Aabenraa - og her skal kun meddeles Hovedtrækkene af det begivenhedsrige Liv, der ligger forud for det Tidsrum (1864-67), hvor Fischers Dagbøger findes fuldt bevaret (Rigsarkivet).

Frederik Fis c her var af gammel Skibsrederslægt, født 1809 i Aabenraa, hvor Faderen var Skibsfører. Selv havde han Lyst til Søen, men Skæbnen nægtede ham endog Evne til at færdes paa den faste Jord. 9 Mdr. gl. blev han lam i begge Benene, saa han kun kom til at krybe om i Stuerne ved Hjælp af en Skammel. Imidlertid fik han som Barn en god Undervisning, mest dog paa Tysk, og paastaar selv, at han ved sin Konfirmation næppe kunde læse en dansk Bog rigtigt. Som Krøbling fandt han let ind i Selvstudiet, og de 6 Aar i Urmagerlære, før han 1830 blev Mester, blev brugt $i$ andre Interesser end de blot erhvervsmæssige. Ved Læsning satte han sig ind i meget af den Sømandskunst, han aldrig kom til at øve i Praksis, saa at han endog paa sine ældre 
Dage kunde læse til Styrmandseksamen med sin Brodersøn, endnu levende Kaptajn C. C. Fischer ${ }^{*}$ ). I Rejsebeskrivelser fandt han Erstatning for de Langfarter, der bliver Sømanden til Del, og han drev endog astronomiske Studier ved $\mathrm{Hjælp}$ af en selvlavet Kikkert. Faa anede, 'hvad der boede i den lille Urmager, at han med alle sine stilfærdige Interesser var en Mand, der med vaagent Blik fulgte Tidens Røre.

Konstit. Borgmester S ch ow i Aabenraa vidste ikke, hvad han gjorde, da han i 1839 gav Fr. Fischer Ret til (paa Tysk) at udgive et "Apenrader Wochenblatt«. Men det var forlængst gaaet op for ham og andre Slesvigholstenere, da Bladet et halvt Aar senere begyndte at udkomme paa Dansk. Sa a farlig var da Fischer. Allerede Aaret før havde han (som "en indfødt Apenrader«) i P. Chr. Kochs "Dannevirke« udtalt sin Hjertens Mening $\mathbf{i}$ de senere saa berømte Ord:

"Danske ere vi, og dansk tænke og føle vi, som Danske have vi Navn i Fortiden og ere kendte over hele Kloden; som Slesvigholstenere - dette Modens Udtryk - ere vi ubekendte saavel i Historien som i vor hele Stilling til Udlandet.“

Det var Fr. Fischers nationale Trosbekendelse.

Iøvrigt var han i sine unge Dage Demokrat. "Jeg anseer det som en Lykke, at jeg ikke alene er en født. Aabenraaer, men i enhver Henseende ved Fødsel, Opdragelse og borgerlig Stilling ganske tilhører Folket«, hedder det $\mathbf{i}$ Fischers Svar paa den Adresse, med hvilken tyske Borgere søgte at standse Bladets Udgivelse paa Dansk. Dette lykkedes dem en føje Tid. Men de faktiske Forhold støttede F. i hans Kamp:

*) Se Sønderjydske Aarb. 1924, S. 175 f. (C. C. Fischers Erindringer). 
Landboerne ønskede ikke et Aabenraablad paa Tysk, naar man fra Haderslev kunde faa Kochs danske Blad. Og fra 1. April 1840 førte »Ugeblad for Aabenraa og Omegn « atter sin Kamp med dansk Sprogvaaben, en Kamp endog for selve Navnet. Men holdt fra anden Side paa "Apenrade" med en Nidkærhed, der gav tyske Doktorer Panderynker, men slog Smil af danske Filologer. Den gamle Skipperby blev kaldt "Schleswig-Holsteins Perle".

Den nationale Vækkelses Aar blev for Fischer en stadig Kamp paa Armodens Rand. Han havde tidligt giftet sig, Børneflokken voksede; for Avisen maatte der betales dyrt hos den tysksindede Bogtrykker Ratje, og Hjemmetyskerne bestræbte sig for at drage Kunder fra hans Urmagerforretning. Men de Danske fik han Liv i, før det var for silde. Hans Hjem blev "Danskhedens Børs« i Byen, hvor Tidens nationale Rørelser gav fintmærkende Udslag. Her sad en Fremtidens Fører som J. P. Junggreen og lyttede med opladt Drengesjæl til de AEldres Tale. Aldrig lod Fischer dem tabe Modet og Troen. Han ænsede ikke den hjemmetyske Ironiseren over, at han kun fik "Stank für Dank« og maatte føle sig svigtet af dem, som just Vagt burde være. Hverken voldsomme Angreb eller lempelige Bestikkelsesforsøg fordrev ham.

Og Bladet hævdede sin Mission. Side om Side med Dr. Manicus' "Flensburger Zeitung " og P. Chr. Kochs "Dannevirke« maa Fischers Blade nævnes.

Hans Virksomhed i Oplysningens Tjeneste fandt endog Anerkendelse hos de nationale Modstandere. Et Lejebibliotek holdt han i mønsterværdig Orden.

Sammen med M a $r$ i in Bah $\mathrm{n}$ s e n vakte han efter Treaarskrigen ny Interesse for Bibliotekssagen og 
gav Stødet til, at 14,000 danske Bøger blev fordelt til sonderjydske Folkebogsamlinger.

Rejsningen 1848 ramte Fischer haardt, i $16 \mathrm{Mdr}$. var han fordrevet, mens Nød og Ødelæggelse truede Hjemmet. Men Aug. 1849 var han atter i Aabenraa og paabegyndte nu Udgivelsen af et nyt Blad, "Freia«, der straks tonede det gamle Flag. Intet Kompromis: »Vi Slesvigere ville netop skilles fra Holstenerne", var Løsenet.

Efter 1850, da Hjemmetyskerne havdé dukket sig, blev Fischers Kamp en væsentlig anden: Nationalistens imod Politikerne. Hans demokratiske Begejstring var kølnet, han fandt, at de Liberale i Kongeriget satte Friheden over den nationale Sag. Fischer omvendt: "Jeg underordner mig ikke den Absolutisme, der bærer Frihedens Vaabenmærke, men trykker mere end noget andet Herredømme«. Og Skandinavismens storpolitiske Maal betegnede han endog som "Graven for det danske Riges Selvstændighed«. Vi kunde se os i Spejl paa Slesvigholstenernes Opgaaen i Tyskheden (en Proces, som iøvrigt Fischers Dagbøger efter 1864 giver adskilligt til Belysning af). Nationalliberale Blade gav skarpt Gensvar, selv Redaktør Bille angreb ham i "Dagbladet". Da Fischer i 1859 overdrog Ledelsen af "Freia« til Svogeren Nic. Sørensen, blev der skumlet om, at Trykket fra et politisk Parti havde været medvirkende Aarsag. Vel vilde F. ikke indrømme dette, men han benyttede Lejligheden til at fastslaa, at ikke a l t var paradoksalt og taabeligt, som fra et Partistandpunkt tog sig saaledes ud.

Kun 50-aarig havde Fischer trukket sig tilbage fra det stadige Bladarbejde. - "Freia« udgik dog fra Trykkeriet i hans Ejendom nede ved Skibbroen - 
desbedre kunde han ofre sig for sine danske Bysbørn paa anden Maade. I hans Stue søgte de Raad i vanskelige Forhold, særlig maatte Fischer tjene som juridisk Konsulent og hjælpe med Affattelsen af mangt et Dokument. Og han tog næppe mod anden Betaling end Tak. Heller ikke med Urene blev det til meget, men sine Vejrobservationer og sin Dagbog passede han flittigt til sin sidste Levedag.

Fischers Da $\mathrm{g} b$ ø $\mathrm{g}$ e $\mathrm{r}$ vidner først og sidst om, at han var en alsidig interesseret Mand og en god Iagttager, dertil en veloplagt Fortæller. En god og karakteristisk Historie slap han ikke paa Halvvejen, og hverken By-eller Landsnyt løb hans Dør forbi. Med usnærpet Vid sagde han engang om sig selv, at han simpelt hen var altfor $n$ y s g e r rig til at være ræd for at dø! Det kunde føjes til, at hans patriotiske Iver og Aktualitetssans var altfor levende til, at han paa Slesvigs Vegne nogensinde kom til for Alvor at frygte den nationale Død.

Fr. Fischer var en Personlighed i Ligevægt. Ikke en uhildet Tilskuer eller Dommer, men en Mand, der bestandig kendte sit eget Tyngdepunkt. Hverken dybe Følelser eller klare Fornuftslutninger rokker hans nationale Haab, mens Uvejret i 1864 driver hen over Slesvig. Da Danevirke er rømmet, og Hjemmetyskerne holder Sejrsfester under den tyske Indrykning, er han fra sit Vindue et satiriserende Vidne til det hele Sceneri. Tiden skal nyttes, mener han. Heller ikke Dybbøls Tab giver dyb Forstemthed, selv Als's kan bæres - først Fredspræliminariernes tunge Vilkaar fylder ham for en Stund med knugende Sorg, der slaar over i brusende Harme. Men to Dage senere fortæller han sindsroligt og omstændeligt Træk fra Tovtrækningen mellem det fredelige danske Bor- 
gerskab og de slet orienterede tyske Myndigheder. Og bestandig morer det Fischer at iagttage, hvor l i d t Prøjserne forstod de kære Stammverwandte, og skadefro bemærkede han de Tegn, der tydede paa, at Slesvigholstenerne ikke selv troede paa deres Stats Mulighed. Kun Hjemmetyskerne er Modstandere, overfor Prøjserne følte F. ingen særlig Uvilje; de menige Soldater har nærmest hans Sympati. Men helt varslende virker en af Krigsaarets sidste Dagbogsnotitser $\left({ }^{28} / 12\right)$, der omhandler prøjsisk Militærdisciplins Brutalitet. "Man ser sig i Spejl herpaa og tænker paa sine egne Børn«.

Som Bidrag til Tidshistorien er Fischers Dagbøger ikke uden Interesse. Hans snart skarpe, snart tillige lune Iagttagerblik er ikke snævert bybegrænset - vi faar et Indblik i de fleste af de Begivenheder, der kendetegner Udviklingen i Nordslesvig i Fremmedherredømmets første Aar: Kirke- og Skolespørgsmaal, Værnepligts- og Forvisningssager, Adressebevægelse og Valgrøre, Stemningen omkring 1866 og Paragraf V osv. - Og Fischers egen Personlighed oplader sig gennem disse Dagbogsblade; men forøvrigt var han den samme i Lønkammeret som overfor Offentligheden. Undertiden har han rettet i sine Optegnelser; som Regel er da et stærkt Udtryk forsvundet til Fordel for et mere neutralt. "Du kender jo hans Maade at udtrykke sig paa, den bliver mangen Gang vel drøj,« skriver. Vennen H. C. Møller, Skovgaard, til H. A. Krüger i Okt. 1867 i Anl. af en Sag, der ogsaa er omtalt i Fischers Dagbøger. Og F. har selv været sig sin Svaghed bevidst. Men i sit stille Sind vilde han sikkert ikke have meget at indvende mod den Karakteristik, en af Augustenborgerens "Spioner" ikke helt uvittigt tildelte ham: en Arkedansker, der næppe 
lettede sig paa den yderste Dag, om Domsbasunerne ikke netop blæste paa Dansk! - En Pat ri ot - i Godt og Ondt - det var Fr. Fischer, et Produkt af en Tid, hvor de nationale Modsætninger blev manges Skæbne.

En af Fischers nære Venner beklagede i et Brev kort efter hans Død, Juni 1871, at ingen ved Graven havde bragt F. det danske Folks Tak. For Fischer selv, i hvis Væsen Beskedenhed rimede sig med Selvbevidsthed, var det sikkert nok, om Nor d s les vig vidste at takke ham med et bevaret dansk Flertal og med sit nationale Haab som en Ildstøtte foran sig gennem Tidens Mulm. Om Fr. Fischer talte Gravstøttens Ord sandt og betegnende:

I mørke Dage som i Dæmringstide

stod Haabet lyst og kraftigt ved hans Side.

Lit t e r a t u r om Fr. Fischer:

"Illustreret Tidende«, ${ }^{27} / 81869$.

"Nordslesvigsk Søndagsblad", ${ }^{27} / 1-2 / 31884$.

P. Lauridsen: Da Sønderjylland vaagnede II 1909-11.

H. Kau: J. P. Junggreen, 1894.

„Sønderjyden«, Juni 1909.

»Sønderjydske Aarbøger", 1924, S. 175-78.

Med Hensyn til U d g i vels e n af Dagbogen for 1864 bemærkes, at mange uvæsentlige Ting (især de daglige Vejrberetninger, en Mængde Meddelelser angaaende Troppebevægelser etc.) enten helt er udeladt eller kun antydet, ligesom enkelte længere Beretninger er forkortet, saa vidt det lod sig gøre uden at ændre Dagbogens Karakter. - At Fischer selv har tænkt sig Dagbogen som et tidshistorisk Dokument, fremgaar af flere Forhold - der er saaledes meget faa Notitser fra Fischers Privatliv, og han har paa 
Dagbogens sidste Blade samlet nogle "Bidrag til Tidshistorien«, bl. a. Udtog af tyske Aviser. Den nationale Interesse er Dagbogens røde Traad.

\section{4.}

De n 1. Januar. Det nye Aar begynder med smukt klart Frostvejr med Østenvind .... Hele Egnen er dækket med et tyndt Lag 'Sne, og paa de oversvømmede Enge Kiil er Iisskorpen en herlig Tumleplads for Skøjteløbere. Fjorden er fuldkommen iisfri... De krigerske Foranstaltninger gaae uafbrudt deres Gang. En Dampkanonbaad ankom om Morgenen til Havnen med alle Slags Requisiter. Om Eftermiddagen kom en Mængde Forstillingsvogne Nordfra. Om Aftenen kom Efterretningen om det nye Ministerium med Monrad i Spidsen.

D e n 2. J a n u a r. Ved Middagstid kom Pantserskonnnerten Esbern Snare hertil, hen imod Aften en Kanonbaad med tvende Transportfartøjer paa Slæb... [De flg. Dage ligeledes Meddelelser om militære Forberedelser til Lands og til Vands.]

Søn d a g d. 24. J a n u a r..... Der blev savet en bred Rende igjennem Isen fra Havnen af til det aabne Vand, og telegraferet til Korsør, at Havnen var tilgængelig. Om Eftermiddagen ankom 150 Dragoner, som droge ud efter Ris til.

D e $n$ 29. J a n u r. [Der landsættes Dragoner fra Kanonbaaden "Marstrand« og to Transportfartøjer.]

Søndag d. 31 . J a n u a r. - Hen paa Eftermiddagen fortælles, at Preusserne ere rykkede ind $i$ Slesvig og at der er forefaldet smaa Sammenstød med vore Tropper.

D e $n$ 2. F e bruar. $4^{\circ}$ Kulde om Natten, om Ef- 
termiddagen slog det om til Tøvejr. Ingen Efterretninger Syd fra.

D e n 3. F e br. - Stærk Tø med Regn hele Natten, og om Dagen tyk diset Luft, af og til med Smaaregn; al Snee er saa godt som forsvunden. - En Deel vilde Rygter circulere. Der fortælles, at 6te Dragonregiment er bleven helt sprængt, at 18de Regiment er bleven frygtelig decimeret, ja fangen tagen og lignende Monstrositeter. - En Dragon, der om Morgenen var brudt op fra Brodersby, i Nærheden af $\mathbf{M y -}$ sunde, havde seet at nogle Huse bleve afbrændte, men vidste ellers Intet....

D e $n$ 4. F e b r..... Fra Flensborg kom i Nattens Løb 300 Syge fra Lazaretterne, der noget efter Middag transporteredes videre til Haderslev. Bladet "Dvk." bragte Beretning om Sammenstødet ved Get torf Mandag den 1ste, hvor 18. Regiment erholdt nogle faa Saarede, om at der var forefaldet Forpostfægtninger ved $\mathrm{K}$ o s e l og B rekendorff Tirsdagen den 2den, samt at sarnme Dag om Formiddagen Kl. 10 et Angreb var bleven foretagen af Tydskerne paa $\mathrm{M} \mathrm{y} \mathrm{s} \mathrm{u} \mathrm{n}$ d, der efter 6 Timers Kamp var blevne tilbageslaaet.

De $n$ 5. F e b r.... Der kom Tidender om Fægtninger for Dannevirke den foregaaende Dag. Om Formiddagen ville Landboere have hørt en stadig Skydning i sydlig Retning.

De n 6. F e b r... Ved Middagstid fortalte Rygtet, at Dannevirke var stormet og indtaget af Tydskerne, en Deel af vor Hær omgaaet og omringet, den anden Deel paa Tilbagetoget o. s. v. Disse Rygter holdt sig og gjentages ideligen. Postgangen or i Uorden .... [Transporter af Syge og Krigsmateriel m. v.]

Søndagen den 7. Februar. Hele Natten igjennem har hersket en overordentlig Bevægelse. 
Talløse Vogne vendte tilbage Syd fra, med Bagagegjenstande og Syge.... Dragonerne forlode Byen tidligt om Morgenen, Trainkudskene vare dragne bort Aftenen tilforn... Restbeholdningen af et Halmmagasin hos Jens Nielsen blev priisgiven til Folket, der ivrigen afhentede Straaknipperne. J. N. lukkede sin Port, men Mængden stormede ind paa den med Hurraraab, sprængte den og tømte Magasinet. Bladet "Dvk." bragte den nedslaaende Efterretning, at Dannevirkestillingen var bleven opgivet... [Om Natten lndkvartering af 12 te Bataillons Forstærkningsmandskab].

D e n 8. F e br. Hele Natten har der hersket en uhyggelig dyb Rolighed i Byen. Det blæste stærkt af Østen og der faldt megen Snee, saa at vi atter bleve forsatte tilbage $i$ Vinteren. Vedvarende ankom enkelte Soldater og Smaagrupper af vor Armee hertil...

D e n 9. F e br. [Fornyet Snefog]. Hele Postgangen afbrudt, om Tyskerne høres intet bestemt, man fabler om at de ere i Bolderslev, i Brunde, ja i Haderslev....

De n 1 0. F e b r..... Stor tydsk Ravage her, da 3 preussiske Dragoner Kl. 10 kom ridende Syd fra igjennem Byen og tilbage. Schleswig-Holsteinske Faner bleve udhængte fra endeel Huse.. ..En Flok tydske Haandværkssvende ledsaget af Drenge, til hvilke enkelte af Byens Indvaanere havde sluttet sig, droge omkring i Gaderne og sang "Schlewigholstein«. Til Gjengjæld sang en anden Forsamling af Haandværkssvende "Kong Christian" og andre danske Sange.... Hen paa Eftermiddagen, da de tydske Svendes Begejstring havde opløst sig i Brændevin, dreve de Parvis dinglende omkring i Gaderne, og umagede sig forgjæves med Repetitionen af den meerumschlungne Vise; 
de forskraalede Struber vare ikke istand til at danne Ord og Toner, og de enkelte Lyd, der hørtes af dem, passede godt til Holdning og Miner. Borgerne holdt sig idethele rolige; kun Enkelte af de Tydsksindede viste en paafaldende Iver.... Hele Situationen havde megen Lighed med en daarlig besøgt Markedsdag. Excesser forefaldt der ingen af .. - Efter Forlydende havde G u s t a v R a b e n sendt Bud ud til Preusserne, at de endelig maatte lade en halvandet Hundrede Mand komme ind i Byen, for Natten over at tjene som Sauvergarde imod befrygtede Udskejelser fra den "danske Pøipels« Side. Men da der kun kom en halv Snes Cuirasserer, paatoge endeel Yngre af de Tydsksindede sig den mere end overflødige Uleilighed at vaage over Byens Tilværelse til næste Dag. De bevæobnede sig med lange Stokke, bandt et hvidt Bind om Armen og spadserede omkring i Gaderne. Som et Bevis paa deres Aarvaagenhed kan anføres, at et Par Fruentimmer, der i Nattens Løb skulde hente Jordemoderen til en Barselkone.... gjentagne Gange bleve antastede af den mandige Nattevagt... Heraf kan man see, hvor precair Byens Stilling har været, da efter Sikkerhedsvagtens Formening tvende Fruentimers Gaaen langs Storegade blev anseet for en farlig Sag.

Den 11. Febr. Nat og Dag det selvsamme taagede Vinterveir med stærk Østenvind og jevnlige Sneebyger.... Fra om Morgenen af ere store Masser preussisk Militair rykkede ind igjennem Byen [alle Vaabenarter repræsenterede].... flere Batailloner indquarteredes i Byen.... De saakaldte schleswigholsteinske Faner have hængt paa Husene Natten over, og flere ere komne til; i hele Byen sees nogle og halvfjerds af dem. Forresten har den hjemme- 
tydske Ilterhed lagt sig Noget. Hen paa Eftermiddagen samlede sig omtrent en halvandet $\mathrm{Hun}$ d re d e Mennesker paa. Søndertorv. Det var Folk fra Byen og Omegnen, en talrig Samling af Skomagersvende med deres Laugsfaner, Tjenestefolk og Børn, men ikke ret mange Borgere. En Musikbande spillede op til Sangen "Schleswigholstein", derpaa fremstod Kjøbmand $\mathrm{J}$ o h a n J a cobse $\mathrm{n}$ og fortalte paa. Tydsk, at endelig havde de brave Preussere, ved for anden Gang at udgyde deres Blod, befriet "uns" ud af det danske Aag og Tyranni, og Hertug Friedrich blev derpaa proclameret. Mængden raabte Hurra, nogle fintklædte Fruentimre svingede Pinde, hvorfra. der flagrede trefarvede Baand, og skrege om Kaps. rned de tilstedeværende Barnepiger, og gamle A mbros i us Wart mei er sad indenfor - nei, s t od op pe i et af sine Vinduer, havde lukket den øverste Rude op og bevægede Hovedet saa hurtigt og ziirligt. som nogen chinesisk Nikkemand. Efter Proclameringen blottede Alle Hovedet og afsang Psalmen "Nun danket alle Gottı! Hvad den stakkels Gud dog skal have Taksigelser for! Nogle tilstædeværende preussiske Soldater sagde rigtignok til hverandre, at det. hele var "Possen und Spielerei - hvem skulde have troet, at le med saa megen Jubel modtagne tydske Brødre kunde have saa lidt Begreb om gribende Momenter. Men værre skulde det komme! Efter fuldbragt Stordaad paa Pottemarkedet marcherede Proclamateuręrne, Skomagersvendene og Appendix op paa Storetorv; men her indfandt sig en slem preussisk Officer med nogle Soldater, som befalede dem at lade være og gaae Enhver til Sit. En henstillet. Tønde, der skulde have tjent som Talerstol, blev af Preusserne sparket ned i Rendestenen... [og den 
preussiske Kommandant viste sig uimodtagelig for Hyldest]. Om Aftenen lod den preussiske Pladscommandant Byens Embedsmænd og Collegier sammenkalde paa Raadstuen og tilkjendegav de Forsamlede, at samtlige Embedsmænd og øvrige Functionairer skulde forblive i deres Stillinger, saalænge som de vilde gaa Haand i Haand med Preusserne, med Hensyn til det Øjemed, for hvilke Sidstnævnte vare komne her ind i Landet. [Den af Bystyrelsen indsatte Indkvarteringskommission forbliver dog].... dersom $i$ det hele nogen Forandring skulde foretages, vilde den blive iværksat af Militairet og ikke overladt til Borgerne. Det befales derhos Embedsmændene at aflægge deres danske Uniformer og Kaarder og paabydes Magistraten at betjene sig af det tydske Sprog ved officielle Udfærdigelser. - Skiltet paa Toldpakhuset blev nedtagen om Eftermiddagen.

D e n 12 . F e b r. - I Nattens Løb ankom 60 Vogne fra Rendsborg med Naturalforplejning til de preussiske Tropper [denne og de flg. Dage stadige Meddelelser om militære Bevægelser].

D e n 13 . F e b r. [Ogsaa Østrigere ankommer].... I'ostmester Has $\mathrm{H}$ lriis og Postholder Hansen bleve arresterede, fordi Førstnæunte havde betalt Sidstnævnte sit Tilgodehavende af Postkassen; paa K a $\mathrm{m}$ m e r h er rens Intervention bleve de dog .... atter frigivne.

Søn dagen den 14 . Febr. Smukt Foraarsvejr; al Iis forsvunden af Fjorden ....- Med Hensyn til det Ydre og den hele Adfærd er der stor Forskjel imellem Preusserne og Østerrigerne. De preussiske Tropper, vi hidtil have havt her, vare alle af Garderregimenterne, smukke, velvoksne Mænd, alle blonde og uden Skjæg; deres Bevægelser vare afmaalte, og 
naar de marcherede gik alt efter en Snor. Østerrigerne derimod vare næsten uden Undtagelse langt under Middelhøjden, deres Holdning mere utvungen, og under Marchen gjorde Enhver sig det saa bequemt som muligt. Preusserne havde Bajonetten paa Geværet, Østerrigerne derimod ikke, og medens Preusserne under Marchen betog sig som paa Excercerskolen, holdt Geværet tæt til Skulderen og gik frem i lige Række, bar den ene Østriger sit Gevær paa sædvanlig Soldatermaneer, den anden med Kolben opad, den tredie havde det hængende i Remmen, kort sagt som Enhver syntes om, og de fulgtes med hverandre uden synderlig Orden. De stærkt besatte Musikcorpser spillede ypperligt.... At Preusserne og Østerrigerne gjensidig saa ilde til hinanden, viste sig strax da begge Nationers Militair traf sammen her i Byen, ringeagtende Yttringer om den anden Nation bleve udtalte til Borgerne fra begge Sider.

Den 16 . Febr. - Om Eftermiddagen ankom Feltmarskalk Wra ngel og Kronprinds Fried rich Wilhel m af Preussen med Stab hertil...

De n 17. F e br.... Vore Stam $[\mathrm{m}]$ verwandte bragte Wrangel og Kronprindsen et Hoch.

D e n 18 . F e b r. [Wrangel til Haderslev]. - Magistraten fik af Bycommandanten den Befaling, at lade Natvægterne raabe tydsk, at forandre Navnene paa Gadehjørnerne til Tydsk og at tilstede, at et preussisk, et østerrigsk og et schleswig-holstensk Flag udhængtes fra Raadhuset.

Sønd a gen d. 21. F e br. - General Wrangel og den preussiske Kronprinds med Stab kom inat her igjennem Nord fra og begav sig ad Sundeved til.

D. 22. F e b r. [Svære Kanonskud fra en Kamp i Alssund; Rygter om afslaaede Angreb paa Dybbøl- 
stillingen]. - De omtalte tre Faner, en sort-guul, en sort-hvid og den trestribede, hænge nu ud af Raadstuevinduerne; det hedder, at de ere lavede af Købmand $\mathrm{H}$ of $\mathrm{f} g$ a a $\mathrm{r}$. Der gaaer ogsaa Tale om, at en talrig Deputation skal afgaae til Hertug Friedrich, og i Forening med andre Deputationer videre til Berlin og Wien. [Talrige Troppemarcher $\mathrm{i}$ den flg. Tid.]

De n 10 . M a r t s. - Henimod Middag ankom ca. 200 krigsfangne danske Soldater, der den 8de vare blevne tagne ved Kolding.... [Dagen efter $96^{\circ}$ til].

D e n 16. Marts.... Man har af og til hørt Skud i Retningen efter Sundeved. Et vildt Rygte fortæller, at der har været en stor Brand i Sønderborg idag. Flere danske Embedsmænd for Jylland bleve som Krigsfanger førte her igjennem Byen.

Den 17. Marts [atter Skud fra. Sundeved].... Preusserne fortælle, at de med deres riflede Kanoner kunne naae Dybbøl Skandser, og deres Prøveskud fra det fastanlagde Batteri har anrettet væsentlige Beskadigelser paa og i Skandserne.

Den 18. Marts. [Efterretninger om Dybbølkampe]... En preussisk Militair som var hos mig i Middagstimen og selv havde deeltaget i Kampen, berettede at denne havde været yderst haardnakket.... Efter hans Relationer havde Danskerne naturligvis lidt et uhyre Mennesketab, Preusserne derimod kun ubetydeligt. En fra $A$ Egtkørsel kommende Bondekarl, der havde været helt ude paa selve Kamppladsen, fortæller derimod, at han har seet Preusserne ligge strøede over Marken som Fluer. Der tales ogsaa om, at Danskerne have frataget Tydskerne to smaa Skandser.... [Kanonade og Røg over Søndenlandet de f]g. Dage].

Den 21. Marts. - Et stort østerrigsk Brotrain 
kom om Formiddagen Nord fra.... De Soldater, der ledsagede det, udsagde, at det var bestemt til Dybbøl....

De n 2. Mart s. - Den preussiske Prinds A lb e r t passerede her igjennem om Morgenen, General Wrangel i Middagstimen, begge kommende Nord fra og gaaende til Flensborg [»Dybbøl« overstreget]. — 150 Vogne ere sildig om Aftenen afgaaede herfra til Graasteen og Omegn. Ingen Skydning er bleven hørt.

Den 25. Marts. [Efter nogle Dages Stilhed atter stærk Skydning]. Her fra Byen bleve 300 Vogne heordrede om til Graasteen. Allerede om Eftermiddagen bragtes flere Saarede til de herværende Lazaretter. - Rygtet gaa $r$ at Femern er taget tilbage af de Danske.

Søndagenden 27. Marts. [Et Dampskib $i$ Fjorden, men sejler atter udefter; stærke Troppebevægelser]. Denne Aften og den paafølgende Nat havde vi den stærkeste Indquartering, Byen $\mathbf{i}$ denne Krig har havt.... Soldaterne vare ved Iilmarcherne saa udasede da de kom, at de næppe kunde slæbe sig afsted.

Den 29. Marts. - Om Natten kom der Expres fra Dybbøl til det herværende Commandantskab, og tidlig i Morgentimen opstod der svær Bulder $i$ alle Gader og Huse, idet de preussiske Indquarterede bleve jagne op af Sengene og skyndsomst forlode Byen, dragende ad Sundeved til...

De n 3 0. Marts. [Prøjsiske Ulahner indbringer tre danske Sømænd, der var landsat fra et Orlogsskfib]. Kammerraad M 11 ar paa Skovgaard blev imorges under Bedækning paa en Vogn kjørt her igjennem Nord paa. 300 Vogne afsendtes herfra til Graasteen..

Den 1. April. - Alle de Aarer, som her ere 
blevne fratagne Baadene og Handlende, vel flere Vognlæs, ere blevne kjørte Syd paa.

Søndagenden 3. A p ri l. - Tydske Militaire tale om, at det med det Allerførste vil gaae alvorligt løs ved Dybbøl, og at der samtidig skal forceres en Overgang paa Als ved Hjælp af Baade og Pontons.

Mandag den 4. A pril. [Efterretninger om Kampe og Brande i Sundeved; Overgangsforsøgene bekræftes.]

De n 5. A pril. - Om Formiddagen stor Bevægelse i Byen, da der viste sig 2 Dampere ude i Fjordmundingen. Alt tydsk Militair der ligger i Byen er udcommanderet til Veirmøllen. Ordonantser kommer farende Nord fra ind i Byen, den ene efter den anden, og det hedder at danske Orlogsskibe have hentet alle Fartøier ud af Gjennerfjord.

D e n 6. A pri l. .... Inat var alt Militair paa Benene, der red Patruiller igjennem Gaderne og uden omkring Byen, da man frygtede et Besøg af danske Orlogsskibe. Alle Munitionsvogne og øvrigt Krigsmaterial blev i største Hastværk kjørt Syd paa, og en stor Deel af vore Hjemmetydskere forlode skyndsomt Byen....

Baade ere afhentede fra vor Fjord og bragte om til Blaakrog. Der siges, at Fiskerne vare flygtede op i Skovene, for at undgaa at blive tvungne til at bringe deres egne Baade bort.

De n 8. A pril. - Om Morgenen hørtes en svær Kanonade fra Dybbøl-Kanten, og der steg en stærk Røg op over Sønderlandet... Om Aftenen Kl. 9 saaes Ildskjær i Retningen af Sønderborg....-- Borgmester L u n n og Herredsfoged B l u m e här faaet Stuearrest og Vagter staaer udenfor deres Huse...

De n 9. A pril.... De saakaldte preussiske Ma- 
rineofficerer [Navne] ere ankomne hertil, og Baadene ved Skibbroen læsses paa Vogne for at kjøres om til Varnæs og Blans. Baadene blive taxerede og loves leverede tilbage igjen efter Taxation.... [De flg. Dage omtales Baadtransporter Nord fra til Sundeved].

[I Dagene 13.-16. April hyppige Brande og stærk Skydning fra Dybbølkanten, navnlig om Natten].

De n 15. A pril... - Der fortælles, at et dansk Streifcorps inat atter har gjort Landgang ved Sønderballe [»i Løjt« overstreget], taget 5 preus. Ulaner tilfange og skudt en Underofficer, der ei vilde overgive $\operatorname{sig} . .$.

Idag ere Borgmesteren, Justitsr. L u n $n$ og Herredsfoged for Ris og Sønderrangstrup Herreder, Kancellir. B l u me, blevne suspenderede af deres Embeder, og Dhr. Ri c hardi og Petersen ere blevne deres resp. Efterfølgere.

De n 16. A prị l. - I Formiddags Kl. 11 mødte vore samtlige fire Raadmænd, ifølge dem tilsendt. Ordre, hos Commandanten, hvor de bleve forestillede den nye Borgemester Richardi, der ved denne Lejlighed ikke sagde et eneste Ord. Commandanten, Ritmester Heiduck, tilkjendegav dem bl. a., at naar han requirerede en af de bedækkede Vogne, som Byen skal stille, saa skulde en af Raadmændene følge med den til Commandantens Bolig, enten det saa var ved Nat eller ved Dag, og forblive ved Vognen indtil han (Commandanten) havde beseet og antaget den. Som Følge af denne Ordre, og efterat Raadmand $B$ a h ns e $\mathrm{n}$ havde talt med den nye Borgemester, indgave Raadmændene Forlangende om deres Afsked. [Natten derpaa demonstrerer Kommandanten sin Magtfuldkommenhed ved at lade Bahnsen stille Vogne til ingen Nytte]. 
Søndagenden 17. A pril. [Der rekvireres Vogne]. - Borgemester Lunn og Herredsfoged Blume ere idag kjørte bort til Flensborg, hver af dem paa en aaben Bøndervogn og omgiven af preussiske Soldater, som simple Forbrydere...

Den 18. A pril. - Kl. $3^{1 / 2}$ i Morges blev der blæst i Gaderne og kort efter rørtes Allarintrommen; Kl. 4 rede Dragonerne Nord ud af Byen. Der fortælles, at de Danske have gjort Landgang i Løjt og taget 3 Ulaner [de andre reddede sig ved Flugt. - En Del af Beretningen overstreget] .... Om Eftermiddagen fortælles, at der er kommet den Melding her til Byen, at Danskerne frivillig have rømmet Dybbøl Skandser. Igaar skulle Preusserne have stormet dem gentagne (man siger 3) Gange, men vare blevne tilbageslagne med uhyre Tab. Imorges IKl. 9-10, da de atter nærmede sig, stode Skandserne tomme og forladte... Senere ud paa Aftenen fortaltes i Modsætning hertil, at et Par preussiske Officerer, som kom fra det Sundevedske, havde sagt, at det forholdt sig ikke som anført, idet Danskerne endnu Kl. 4 Eftermiddag havde Skandserne i deres Magt, og at der ingen Udsigter fandtes til at tage dem saa snart. - Det hedder ogsaa, at Kongen af Preussen i egen Person er ankommen til Sundeved. I dag ere ingen Kanonskud hørtes i d e n i M or ges K 1. 8. [I Paranthes anføres s e n e r e Efterretn. om Stormen paa Skandserne].

D e n 19. A pri 1. - Angaaende Dybbøl Skandser cirkulere en Masse Rygter.... Det hedder bl. a., at Preusserne fra deres vestlige Fløj vare brudt ind bag Skandserne og havde angrebet dem bagfra og forfra tillige, - at de ogsaa havde taget Brohovederne, at $3000 \mathrm{Md}$. Danske var tagne til Fange, - at $5000 \mathrm{Md}$. Preussere vare gaaede over paa Als osv. Trods alle 
disse Overdrivelser hersker der dog en synlig trykket Stemning iblandt vore Hjemmetydskere, hvilket vidner om, at Resultatet af det Skeete er under deres For-

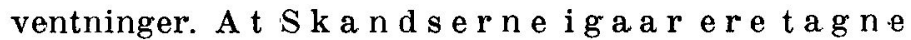
d e rom er der inge $\mathrm{n} T \mathrm{viv}$, og at ogsaa mange Fanger ere faldne i Preussernes Hænder er notorisk, thi navngivne Personer have seet dem blive bragte igjennem Flensborg....

Den 20. April. [Nøjere Efterretning om Tabene ved Dybbølstormen]. Ogsaa Brohovederne ved Alssund bleve tagne samme Dag som Skandserne. Ved Middag afrejste endeel af vore tydsksindede Borgere til Dybbøl....

Den 21. A pri 1. - ... Efterretning om at Kongen af Preussen vilde indtræffe hertil og holde Revue over Tropperne. Vor By har i Dag en Besætning af ca. $7000 \mathrm{Md}$, for det meste Gardesoldater. Der gjøres Forberedelser til den preussiske Konges Modtagelse; Eresporten reises ved Veirmøllen o. s. v. - . Der høres af og til svære Kanonskud fra Sydøst.

De n 22. A pri 1 (Bededag). Smukt Veir... Der har hersket stor Bevægelse her i Byen fra den tidlige Morgen af [Militæret rykker ud].... Man havde seet 4 Dampere ude i Fjorden og belavede sig paa Alt. Skibene forsvandt imidlertid igjen, paa det ene nær, der i lang Tid har havt Station derude. - De preussiske Tropper rykkede ud til Stubbæk, hvor Kong Wi lh e $1 \mathrm{~m}$ indfandt sig [og] lod dem paradere. Hvad han har sagt til dem, har man ikke erfaret. Derimod fortælles, at en Flok unge Piger, Døttre af vore første Hjemmetydskere, har begivet sig til Stubbæk, for at overrække Preusserkongen Krandse og bede ham om at gjæste vor By. Men han afviste dem og skal have sagt, at han kun var kommen for at see til sin Armee 
og vilde ikke indlade sig med Privatfolk. [Med sit Følge, hvori saas Kronprinsen, Prins Friedrich Karl og General Wrangel, red han kun ned til Fjorden ved Styrtom]. - "Altsaa kom Goldkalb ikke til Staden, skammeligt bleve narrede vi“ - hedder det i Visen, og saaledes have vore Stammeverwandte vistnok tænkt tusinde Gange denne Dag. Man havde belavet sig paa en stor Høitidsdg her i Byen. Paa Skibbroens Flagstang var for forste Gang i denne Krig heiset det trestribede Flag, ligesaa paa Galgebjerg, og til de tidligere fra Privathuse udhængte var komne nogle nye, t. E. hos $\mathrm{H}$ u n d ew adt, H. Davidsen. Gaderne vare paa mange Steder bestrøede med Blomster og Grønt, en Ereport reist ved Veirmøllen og en ditto ved Callesens Teglværk. Alt spildt Umage, han kom ikke. Derimod kom der nok af hans Soldater. I flere Timer drog Tropper her igjennem Byen Nord paa, med klingende Spil og seiersstolte Miner, deres Pikkelhuer for en stor Deel prydede med Krandse, Blomster og Grønt....

De n 23. A p r i 1. - De her indquarterede Tropper ere afmarcherede til Haderslev.... - Den hidtilværende Commandant, Ritmester $\mathrm{Hei} \mathrm{d} \mathrm{uk}$, er afreist med sin Eskadron, og hans. Efterfølger som Commandant er bleven en Major $L$ ü d e r it z med Ulanerne.

Den 26. A pril. - Iformiddags passerede en Deel af Wrangels Stab her igjennem og gik Nord efter. Commandanten lod tilsige $i$ alle Huse, at der skulde sættes Lys i Vinduerne, naar der om Natten blev slaaet Allarm eller blæst i Gaderne. Han skal have yttret, at han med Vished forventede et Overfald af de Danske, men var betænkt paa at møde det. [De flg. Dage stadige Troppemarcher og Materialtransport]. 
Den 3 0. A pri l. - Der fortælles overalt, at Fridericia igaar Eftermiddag er bleven forladt af Danskerne, og besat af Tydskerne uden nogen Kamp.... Forresten hersker der her i Byen idag en Rolighed og Stilhed, der paafaldende afstikker fra den Tummel og det Røre, som vi Dag ud, Dag ind have været vante til.

Søn d a g d e n 1. M a j. [Fredericias Overgivelse bekræftet] .... Tydskerne her hovere slet ikke derover, den dansksindede Menigmand er glad ved at saa mange Liv derved blive sparede. Vi ere meget spændte paa at erfare, paa hvilke Betingelser Overgivelsen er sket, og tvivle ikke om, at det er Diplomatiens Værk, at det er kommet saaledes. .... - Tilstanden her i Byen er højst mærkelig. Alle Retssager hvile. Borgemester Richardi har været frareist i 5-6 Dage. Hundewadt er hans Fuldmægtig, og alle Udfærdigelser fra Contoiret skee i det tydske Sprog. Raadmændene have intet Svar faaet paa deres Andragender om deres Afsked og fungerer derfor factisk endnu. Ligesaa alle andre Bestillingsmænd og Functionairer. Min Broder er endnu Havneinspecteur, skjøndt Borgmesteren den Dag, da Gust. Ra. ben vilde have det trestribede Flag heiset paa Skibsbroen, sagde til Brovægteren, at han nu skulde lystre Raben og ikke bryde sig om Fischer [denne forhindrede dog, at G. Raben fik Mudderapparaterne i Virksomhed paa sit Værft!]

D e n 2. Ma i. - Et stort Antal Embedsmænd fra de sydligste jydske Kjøbstæder kom som Fanger paa Agtvogne hertil under militair Bevogtning og blev expederet til Rødekro, for paa Jernbanen at bringes Syd paa. Deres Vægring [ved] at udskrive de uover- 
kommelige Contributioner skal have bevirket deres Arrestering og Bortførelse.

$\mathrm{D}$ e $\mathrm{n}$ 3. M a i. - Imorges have vore hidtilværente Raadmænd erholdt den af dem forlangte Afsked.... - En preussisk Hr. Stiel har idag, ledsaget af Borgemester Richardi, været omkring i Skolerne og erkyndiget sig om, hvorvidt der undervistes i Tydsk; Disciplene maatte heri aflægge Læseprøver.... Med Hensyn til den nye Magistrat fortælles, at til ældste Raadmand var udseet Jørgen A h lmann, men som havde Betænkeligheder ved at modtage Posten, hvorfor den indtil videre forblev ubesat. De øvrige Raadmænd skulle være Marc. H. L üd ers, B. B. Jessen og Gustav Raben. - Der omtalte Hr. Stiel .... har ogsaa besøgt Assessor D e i c h m a n n s Institut. Han spurgte bl. a., .... hvor mange Timer der gaves Undervisning i Tydsk, og syntes overrasket ved at høre, at der undervistes deri ugentlig 6-9 Timer - om Aarsagen, hvorfor .... Historien om Tydskland ikke foredrages efter tydske Lærebøger. Da Assessor Deichmann fjernede sig for at hente Timetabeller og Prøver om Disciplenes Duelighed fra tidligere Aar, indlod han sig i Samtale med Skoleeleverne spurgte om deres Forældres Stilling, om de talte Dansk eller Tydsk hjemme o. s. v.

Den 5. Mai. - En Deel af de jydske Bortførte er paa Hjemreisen kommet her igjennem.

D e n 6. M a i. - Det erfares, at vor Borgemester, Justitsraad Lunn, og Herredsfoged, Kancellir. Blume skulle omsider være frigivne, uden at der er fundet Grund til deres strenge langvarige Arrestering; ogsaa fortælles, at de $i$ al den Tid, de have siddet [i] Flensborgs Arrester, slet ikke have været taget i Forhør. [Hjemkomsten omtalt den 8de.] 
De n 7. Ma i. - I de sidste Dage ere betydelige Masser af østerrigske Tropper af alle Vaabenarter komne Nord fra forbi Rødekro, ligeledes Train og Rustvogne. Bestemmelsen skal være Besættelsen af den slesv. Vestkyst. [Østrigske Orlogsskibe for Elben den 5te.]

Søndag den 8. Mai. - Idag have vore Hjemmetydskere begivet sig paa en almindelig Valfart til Rendsborg, hvor der skal afholdes en stor Folkeforsamling for at sikre Schleswigholsteins Fremtid. Der er allerede $\mathrm{i}$ en længere Tid bleven gjort Forberedelser til at faa ret mange drevne til Rendsborg, og den nye Jernbane er et ypperligt Middel ... Et Sendebud har været omkring hos alle, som man kunde have Formodning om at der vilde deltage $i$ Toget, og der gives .... fri Befordring saa vel frem som tilbage. Det. er altsaa begribeligt, at mangen Een, der forresten ikke er saa varm i Tøjet, ikke lader saa billig Lejlighed til at gjøre en Lysttur, maaskee for allerførste Gang i sit Liv at kjøre paa en Jernbane, gaae ubenyttet forbi .... [En ved Vaadeskud dræbt Soldat begravet.] Man fortæller, at Lüders har været hos. Commandanten for at faae Begravelsen opsat til imorgen, da Expeditionen til Rendsborg idag havde fjernet saa mange Gesinnungstüchtige .... Den meget fornuftige Commandant, der ikke maa kjende Schleswigholsteinernes Manerer, kunde ikke begribe, hvorfor L. sværmede saa meget for et stort Liigfølge; men omsider kom han paa den Tanke, at en meget. materiel Grund kunde ligge bagved de smukke Talemaader og yttrede sin Formodning til L. i det Spørgsmaal: "Sind Sie vielleicht de $\mathbf{r}$ K ü s t e r." Det var koldt Vand paa den varme Begejstring. Uden at værdige den Spørgende et Svar dreiede L. sig om og 
forlod 》in höchster sittlichen Entrüstung« Værelset.

De n 10 . Ma i. - En stor Mængde Quæg, som Fjenderne have frarøvet Beboerne i Jylland, er idag bleven drevet her igjennem .... Endog preussiske Menige udtale deres Afsky over dette Røveri, kalde det "geradezu Raub und Diebstahl« o. s. v. Det er rimeligviis Sønner af Landmænd, der udtale sig paa denne Maade ....-Vi modtoge Efterretningen-om den afsluttede 4-ugers Vaabenstilstand og om Søtræfningen ved Helgoland.

D e n 11. M a i....- Om Aftenen Kl. 9 opstod der stor Bevægelse her i Byen. En Ordonnants kom sprængende og meldte, at en Kanonbaad og et andet. Fartøj vare løbne ind i Gjenner Bugt .... Forfærdelsen var stor iblandt alle Tydsksindede. Nogle begave sig strax paa Flugten ud af Byen ved første Allarmsignal, alle tydske Flag forsvandt paa een gang. Selv et Lazareth gav man sig til at flytte .... [De til Gjenner afsendte Tropper saa dog ingen Fjende.]

D e n 14. Ma i. - Atter ankom en stor Transport af Quæg fra Jylland. Det preussiske Militair kan ikke undertrykke sin Misbilligelse af det Plyndringssystem, som deres egne Befalingsmænd udøver imod de stakkels Jyder. [De borttransporterede Baade bringes noget ramponerede tilbage, en Del af dem havde dog ikke været af Vognene.]

Den hidtilværende Commandant, Ulanmajor Lüderitz, er idag tagen bort med sin Escadron, og Commandantskabet gaaet over paa Chefen for den her liggende preussiske 15de Infanteribataillon. Major Lüderitz har vist sig som en særdeles human og fornuftig Mand.

Søndag den 15. Mai (første Pintsedag). Ogsaa idag ere Heste, som Preusserne have tagne i Jyl- 
land, komne her igjennem [ogsaa Kreaturtransporterne vedvarer]. - Der er i den sidste Tid foretaget Kirke- og Skolevisitats i Ulderup, Felsted og Varnæs af Kammerh. H e l $\mathrm{t} z$ e $\mathrm{n}$ og den const. Provst G o d t. I Ulderup mødte hverken Voxne eller Børn, ikke engang Kirkeværgerne. Provsten vilde Pastor Feilb e rg tillivs, idet han fremdrog et Papiir af Lommen og sagde, at det var en Copi af, hvad Feilberg efter det forrige Oprørs Undertrykkelse havde indført i Skriftebogen. Men Feilberg afbrød ham og forelæste uden mindste Betænkelighed hvad han havde skrevet i Skriftebogen, og hvor han i haarde Udtryk udtalte sig om Oprøret og dets Ledere. Provsten yttrede spydigt, at han ikke kunde forstaae, hvorledes Feilberg, efter at have udtalt sig paa anførte Maade, kunde finde sig $i$ at lystre de nuværende Civilcommissairer og underskrive den af dem fordrede og udstedte Revers. Men Feilberg svarede, at Magthaverne under den forrige Krig vare Rebeller, de nuværende Civilcommissairer derimod indsatte af Hs. Majest. Keiseren af Østerrig og Hs. M. Kongen af Preussen, og saa længe Vorherre kunde finde sig i, at deres Magtherredømme skulde bestaa, kunde Præsten i Ulderup det ogsaa. Provsten taug.

Den 16. Mai... - I Felsted havde mange Bønder indfundet sig til Visitationen i Kirken, og Provst Godt, som før 1848 var Præst der, men blev afskediget paa Grund af sin Delagtighed i Oprøret, ansaae dette som et Bevis for, at man endnu holdt af ham, og talte i høje Fraser om, hvor kjært Beviiset paa en saadan udholdende Kjærlighed var for ham. Men han fik snart at vide, at Sagen havde et andet Sammenhæng. Da efter Visitationen i Kirken Hr. Provsten i Skolen talte med Past. Hansen og fore- 
holdt ham, at han efter Sigende havde holdt politisk Foredrag fra Prædikestolen, svarede den Tiltalte med et bestemt Nei; han havde kun paa den bestemte Søndag prædiket om Mened og advaret imod denne Forbrydelse. Men da Provsten blev ved at beskylde Præsten, begyndte først en heftig Mumlen iblandt de talrigt forsamlede Bønder, der stode udenfor de aabne Vinduer, og denne Mumlen gik tilsidst over til høje Raab: "Det er Løgn! Sig, hvem der har fortalt det!« naar Provsten paany fremkom med sine Beskyldninger mod Pastor Hansen. Stemningen iblandt Bønderne blev tilsidst saaledes, at Kammerhr. Heltzen maatte berolige den forfippede Provst med den Forsikring, at han ikke havde noget "personligt« at befrygte.

De n $17 . \mathrm{M}$ a i. - ... . Det er idag »Skyttelaugsdagen«, den største Festdag i hele Aaret for Aabenraas Almue og Ungdom, en sand Dyrehaugstid af 24 'Timer. Men Skyttelauget holder dennesinde ingen skiveskydning, og de tydske Soldaters talrige Tilstedeværelse .... har aldeles udslettet Folkelighedens Præg.

De n 1 8. Ma i. - I Eftermiddags kom en Transport af svært Skyts fra Fredericia her igjennem. Alt var fornaglet, ligesom det tidligere .... Skibsfarten aabnede med, at den nybyggede norske Skonnert "Gerda"idag afseilede herfra til Kbhvn. -

Idag jordedes i Haderslev Danskhedens højtbegavede Talsmand, La u rids Skau. Et Følge af 6-700 Mennesker, der alle frivillig vare mødte, ledsagede ham til hans sidste Hvilested. Ogsaa her fra Byen vare 14. Personer reiste til Haderslev, for at vise den Afdøde den sidste Are.

D e $\mathrm{n}$ 21. M a i. - [General Wrangel paa Gennem- 
rejse.] Vore Hjemmetydskere havde gjort Forberedelse til et Fakkeltog, da man antog, at han vilde være blevet for Natten, men hans hurtige Afreise forhindrede Planens Udførelse. Der fortælles, at Kbmd. F. A. Jensen og Gustav Raben havde den Uforskammethed at forlange af Toldforvalter, Kammerraad Møller Grene af et ham tilhørende Lavrbærtræ til en Krands til den gamle Preussergeneral, en Anmodning, som Kammerraaden afviste med fortjent Harme. De beklagede sig nu hos den preussiske Commandant, men denne gav dem ingen Medhold ....

De n 26. M a i. - [Atter 20 Kanoner fra Fredericia]. - En allerede igaar hertil ankommen Skrivelse fra Civilcommissairerne har afskediget vore Deputerede, og ved en Magistratsskrivelse er Bahnsen fritaget for sine Functioner ved Gasværket, Vandværket, samt Kirke- og Skolebygninger. Man stræber med at gjøre ryddeligt, mens man har Magten i Hænder. Forresten ere vore Hjemmetydskere meget. modfaldne, fordi Aviserne have bragt den Efterretning, at England og Frankrig holde paa Delingen af Slesvig. De trestribede Flag .... ere paa nogle faa. nær forsvundne. [En Baad-Erstatningssag vækker Opsigt. Blev Fiskerne narret til som »Kvittering« at underskrive en tysk Adresse?]

D e n 27. Ma i. - Veiret vedvarende saa raat og koldt, at jeg atter lagde Ild i Kakkelovnen .... Ikke tilfreds med at have affordret samtlige i Embeder ansatte Personer den skriftlige Erklæring, at de [under Okkupationen] vilde holde sig den øverste Civilautoritets (d'Hr. Zetlitz og Revertera) Anordninger efterrettelige, har nævnte øverste Civilau- 
toritet $\mathrm{i}$ den senere Tid af Præsterne forlangt en ny Revers [Lydighedserklæringen anføres].

D e n 28. M a i. - Paa Kirke- og Skolevisitatsen i Østerløgum fandt Provst Godt Intet at klage over. [Et Par Mænd fra Hovslund yttrer Ønske om at faa en tidligere Præst igen, der i 1850'erne var afskediget for Oprørstendenser. Ved at høre denne Begjæring, som Provsten syntes at ville tage venlig imod, reiste sig Kammerh. Heltzen og sagde, at han fandt det besynderligt at tale om at faa den lovlige Præst, da han i Pastor Binzer jo var tilstede. Det lovlige Kirkevisitatorium havde til sin Tid sat ham paa Valg, Menigheden havde valgt ham, og H. Majest. den afdøde Konge bekræflet Valget, saa at den fulde Lovlighed ved Pastor Binzers Function som Præst var tilstede. Han henvendte sig derpaa til Forsamiingen med Forespørgelse, om Nogen havde Klage at fremføre imod Pastor B., men Alle raabte som af een Mund, at de slet Intet havde at klage over, men i alle Henseende[r] vare fornøjede og tilfredse med deres nuværende Præst og hans Virksomhed [Provsten maa da indrømme, at de to Mænds Krav ikke kan komme i Betragtning].

Søn d a g d e n 29. M a i. - Paa Skibsbroen vajer atter det trestribede Flag. Det skal bruges, mens Tid er, tænker vistnok Vedkommende ....

$\mathrm{Den} 31 . \mathrm{Ma}$ i. [Ingen sikre Efterretninger om Londonkonferencen]. Hvad de tydske Aviser derom beretter, bærer Upaalidelighedens Præg og er ikke engang overensstemmende. Vore Hjemmetydskere have i Søndags tvende Gange telegrapheret til Hamborg for at faa Noget at vide om Conferencens Beslutninger, men forgjæves. De ere i stor Angest over 
Delingsprojectet, men søge at trøste sig ved Tanken om, at Delingslinien vil blive trukken ved Gjennerbugt.

De n 1. J u n i. - Vort nye Deputeretcollegium er bleven organiseret og bestaar af: Kjøbmand Herman Davidsen, Bager Asmus Andresen, Skomager Christiansen, Snedker Gebhardt, Kbmd. Ludolph Davidsen, Commiss. Hundewadt, Kbmd. F. A. Jensen, Kbmd. Hoffgaard, Gjæstgiver Krause, Snedker Joh. Petersen, Tobaksfabrikant H. Offersen og Smed J. M. Holst. .... Som man hører har det nye Deputeretcollegiums Dannelse vakt megen Utilfredshed i vor hjemmetydske Leir. "Bürgerverein" anseer sig for fuldkommen berettiget til at vælge det nye Collegiums Medlemmer iblandt Sine, og der vare Mange, som vilde være Noget .... Man var derfor højligen entrüstet over, at Borgemesteren og hans Raadmænd ikke anerkjendte "Bürgerverein«s Beføjelse til omtalte Valg, men selv udførte dette. Saa stor var Misnøjen herover, at der løde Ord om at Borgemester Richardi kun skulde betænke, at "wir" havde faaet ham i sin nuværende Embede, men at "wir" ogsaa kunde faa ham ud deraf igjen. Iblandt de mangfoldige Aspiranter til Deputerede skal især Bager Jacob Mich. Lorenzen have givet sin Harme over at være forbigaaet Luft i kjærnefulde Udtryk. "Der har di wahl den, der int eier für Skilling, seier æ sin, en Kahl som hverken hær Forstahn eller gier nowt i Skat; de er jo reent Keltringeri de hele, seier æ sin; hvorfor taw di int mæ dertæ; er de Frihed, seier $æ$ sin!« - og han svor paa, at nu skulde det trestribede Flag aldrig mere komme til at vaje fra hans Huus.

D e n 4. J u n i. - Der tales Meget om en nærforestaaende Udskrivning af Recrutter, der under Preus- 
sernes Egide skulde skee for at skabe en Armee til Prætendenten, og det hedder, at mange unge Værnepligtige allerede havde absenteret sig af Frygt for at blive tagne .... Selv tydsksindede Fyre erklære, at de, hvis det skulde komme dertil, vil rømme - til Fyen. Ogsaa gaaer Ordet, at der i Morgen skal afholdes et schleswigholsteinsk Møde ved Rødekro, og paa Mandag ved Haderslev, for at faa Landboerne til at erklære, at de ikke ville blive Nørrejyder, men forblive forenede med deres sydslesvigske Brødre.

Sø n d a g d e n 5. J u n i. Mødet ved Rødekro have Hjemmetydskerne opgivet, men imorgen skal der holdes en stor Forsamling ved Haderslev, hvor Creti og Pleti skal møde, og hvor man vil søge at tilintetgjøre de Beslutninger, Conferencen i London maatte komme til, hvis de ikke svare til vore Teutoners Ønsker.

Den 6. J u n i. - Fra den tidlige Morgenstund af ere Vogne kjørte til Haderslev med fuld Bepakning af Stammeverwandte af alle mulige Kalibre. Fra de fyldte Dagvogne lød "Schlesw. Holst. meerumschlungen«, og de[t] sees tydeligt, at det er Folk fra langt sydligere Dele af Hertugdømmet, der sendes herop for at "vidne" om, hvad Nordslesvigere egentlig ville [saaledes Frisere og Folk fra Eiderstedt] .... Her fra Byen vare afreiste og afsendte mange Vognlæs "Gesinnungstüchtige», frivillige og ufrivillige, kjøbte og solgte; paa G. Rabens Værft feiredes hele Dagen, og efter Sigende havde hver Tømrer faaet en Thaler preussisk til Haderslevreisen, dog foretrak mange af dem at blive hjemme. At alle trestribede Flag atter var hængt ud her .i Byen, er en Selvfølge. Allerede om Eftermiddagen Kl. 5 kom de første Vogne tilbage og .... kjørte tause og rolige ind i Byen, men 
længere ud paa Aftenen kom de Inspirerte. Det kneb kjendeligt for mange Struber at [faa] den meerumschlungne Vise ført ud, men den maatte til, hvorledes den saa end lød, og i alle Musikkens Tonarter bruste Begeistringen ned fra Agerstole og ud af Dagvogns Vinduer. Her i Byen havde en Deel, af Tøm* rerne .... samlet sig i adspredte Smakklynger, der vandre omkring i Gaderne, og med skjemtsomme Ord modtoge de Tilbagevendende. Men snart paakom ogsaa dem Lysten til at synge, og »den tappre Landsoldat« lød nu lige saa kraftigt i vore Gader som i fordums Tider. Preusserne morede sig synlig over det hele Skuespil, og ikke faa af dem satte Fingrene mod Næsen efter de ladskede Skikkelser, der skraa-. lede fra Vognene.

D e n 7. J u n i. - [Tyskernes Vogntog vedblev til ud paa Morgenen]. - Hvad der .... er bleven udrettet ville vi faa at vide med Tiden; det synes ikke at Vore Hjemvendte have medbragt synderlig Encouragering. - Det hedder, at G. Raben, Hoffgaard og Hundewadt her fra Byen i Forening med Flere ere afreiste som Deputation til Berlin, for at overrække Kongen af Preussen den i Haderslev igaar underskrevne Adresse.

De n 8. J u n i. [Rygter - til Dels Iagttagelse vedr. store preussiske Troppebevægelser mod Sundeved].

De n 10 . J u ni. - Rygtet har gaaet, at der idag skulde komme en Mængde preussisk Militair hertil, men nu hedider det, at der er givet Contraordre, fordí Vaabenhvilen er bleven forlænget i 14 Dage.

De n 1 3. J u n i. - Hen imod Middag lettede det nye Barkskib "Samson«, Kpt. Kjær, tilhørende $\mathrm{H}$ o h lm a n n i Loejt, sit Anker og krydsede fra Rheden ud 
af Fjorden. Det havde intet.Flag heiset .... Som man hører skal det gaae til Assens og der forsynes med dansk Skibsmærke og danske Skibspapirer. Saalidt troe Schleswigholsteinerne selv paa deres Stats Mulighed, at de, hvor det kniber, søge ind under dansk Beskyttelse ....

De n 14 . J u n i. - [En Telttransport Syd fra]. Ogsaa siges, at der ved Flensborg staaer en Mængde store Pramme, som skulle være bestemte til at udføre en paatænkt Overgang til Fyen med.

De n 21. J u ni. - Idag afholdes en af Hjemmetydskerne foranstaltet Folkeforsamling ved Løgumkloster. Her fra Byen ere kun Folk af de lavere Classer af nævnte Race sendte derhen, da alle de andre, selv Haandværksmestere, gaae her hjemme i Gaderne, ikke at tale om de tydske Stormænd selv, af hvilke ikke een er reist til Løgumkloster. -

Senere modtagne Beretninger godtgjør, at det omtalte tydske Foretagende er aldeles slaaet feil. Hele Forsamlingen bestod af nogle faa Hundrede af Mennesker, hvis Udseende og Adfærd røbede deres underordnede Betydning og Stilling i Samfundet. Naar "Apenr. Nachr." Nr. 9 angiver, at 5000 Mennesker var der tilstede, er idetmindste det ene Nul formeget.

D e $n$ 2 2. J u n i. - Hen imod Aften løb Emil Hansen omkring fra Huus til Huus, for at bringe sine Venner den Melding, at han havde faaet en Telegraphdepeche fra Hamborg, hvorefter Conferencen i London. havde opløst sig, og Krigen var erklæret Tydskland af England .... Inat taltes om ikke andet i hele. Byen, selv det tydske Militair troede derpaa. [Næste Dag viste dog, at Meddelelsen var falsk].

Den 23. Juni. [Omtale af det besynderlige Forhold, at Gustav Raben har onsket sine Skibe be- 
tegnet som "Dansk Eiendom", hvad Toldkammerets Arbejdsmand Brunshuus dog ikke turde gaa med til uden Ordre.]

Den 24. Juni. .... Det hedder, at den tydske Armees Generalstab vil ankomme hertil imorgen og tage sit Hovedquarteer her i Byen for en Iængere Tid. [Hjemmetydskerne ønskede at rejse Aresport, men den prøjsiske Overledelse hindrede det ved sin bestemte Indsigelse].

Den 25. J u ni. - Alle de schleswigholsteinske Flag ere idag stukne ud i Anledning af Prinds C a r ls Ankomst ....; ogsaa paa Galgebjerg vajer den trestribede Klud, men, mærkeligt nok, ikke paa Skibsbroen .... Foran enkelte Huse er Gaden bestrøet med Blomster og Grønt ....

Søndag d e n 26. J u n i. - [Vaabenhvilens Afslutning kendetegnes ved flere Brovagter og ved Baadtransporter mod Sundeved] .... Der hersker her i Byen en paafaldende, næsten ængstigende Stilhed. Ikke mindste Bevægelse af Militair eller Krigsmateriel hentyder paa, at Fjendtlighedernes Periode atter er indtraadt. [Iflg. Telegram fra London skulde det. slesvig-holstenske Spørgsmaal nu være ordnet.]

De n 2 7. J u n i. [Kun lidet Nyt; Fredsrygterne ubekræftede; Artilleriet brød op mod Sundeved, men fik Kontraordre]. - Det stadfæstes, at der igaar er bleven ført en Artillerikamp ved Alssund, ligeledes har man idag jevnlig hørt Kanonskud .... Præsterne Roth i Varnæs, Mørk Hansen i Felsted og F e i lb erg i Ulderup ere for fjerde Gang blevne fængslede og bortførte af Preusserne. Hvad Farlighed for Krigsførelsen disse kunne finde ved de stakkels tre Præster, er ikke let at begribe, men der ligge sagtens. andre Bevæggrunde bagved. 
v. Zetlitz, den ene af Civilcommissairerne, er idag her i Byen.

De n 28. Juni. - Igaar Aftes har Ka m mer$\mathrm{h}$ er re $\mathrm{H}$ e $1 \mathrm{tz}$ e n omsider faaet sin Afsked meddeelt fra Civilcommissairerne, med Tilkjendegivelse om, at det skeete ifølge Militairautoriteternes Forlangende, der ansaae hans Nærværelse her for farlig for de allierede Armeers Sikkerhed. [Det var alm. ventet] .... og han selv kan sikkerligen .... ikke være Andet end tilfreds med, at han frigjøres for en Stilling, som han kun af Hensyn til det Almindelige har holdt ud i saa længe under Omstændigheder, der for ham have maattet være i højeste Grad piinlige. Iaften fik ogsaa Amtsforvalter Justitsr. W or s a a sin Afsked.

D e n 29. J u n i. - Strax om Morgenen modtoge vi den Tidende, at Als inat er bleven tagen af Preusserne. Man har hele Natten igjennem hørt en heftig Kanonade, selv paa Varnæshoved var der bleven anlagt et preussisk Batteri, der fyrede paa Skibene. Om det Speciellere erfares Intet, imedens Rygtet som sædvanligt fortæller tusinde Ting, t. E. at »Rolf Krake« er bleven boret isænk, ja, endog erobret [prøjs. Militære afkræftede dog dette Rygte]. At Meldingen om Indtagelsen af Als har udøvet en nedslaaende Virkning paa alle Dansksindede, er begribeligt, ligesom at Hjemmetydskerne derover er paa den store Støvle.

Som man hører er paa et igaar afholdt Møde af Kirkevisitatoriet, hvori Exprovst $\mathrm{R}$ e $\mathrm{h} h$ of $\mathrm{f}$ deeltog, Compastor $\mathrm{Hol}$ d bleven udnævnt til dansk Diakonus her i Byen.

De n 3 0. J u ni. - Exprovst $R$ e $\mathrm{h} h$ of $f$ er atter afreist, uden at faae attaqueret ogsaa Skolerne, som 
man antog vilde skee. Folk som have seet den meensvorne Klerk skildre hans Udseende og Figur som et levende Billede af den onde Samvittighed. En høj hentørret Skikkelse med gustent Ansigt, det sænkede Blik fæstet paa Jorden, vandrede han frem med usikre Skridt, Hænderne lagde sammen paa Maven.

De n 1. J u li. - Idag hersker stor militair Bevægelse her i Byen [bl. a. gælder det Forberedelser ti] Fyns Erobring] .... Prinds Carl har i Eftermiddag paa Storetorv udøst sin kongl. Højheds Vrede i meget markerede Udtryk paa en høj preussisk Officer, og ved samme Leilighed højst egenhændig slaaet August Herzog til Jorden, fordi han kom ham vel nær. Dengang Kong Frederik VII ifjor den 2den October var her og forlod vor By, saae jeg, da han kjørte forbi mit Huus, hvorledes en Mylder af Børn omgav hans Vogn og trængte sig saa nær ind paa den, at Kongen slog med Haanden og sagde gjentagne Gange: "Tag Jer dog iagt, I kommer til Skade! ... Hvilken Contrast imellem den danske Konges og den preussiske Prindses Adfærd!

De $n 5$ t e J u li. [De danske Embeds- og Bestillingsmænd skal sige sig løs fra enhver Forpligtelse overfor den danske Regering eller frivilligt nedlægge deres Embeder]. Physicus Dahl erklærede, at han hverken vilde eller kunde ansee sig som løst .... og eiheller vilde frivilligt fratræde sit Embede. Adv. L e t $h$ udtalte, at han ikke stod $i$ nogen Embedsstilling, men kun af Staten havde faaet den Frihed at gjøre sine Kundskaber frugtbringende som Advokat, han vilde ikke frivilligt opgive denne Rettighed; han havde ved den tidligere indgivne Erklærng anerkjendt, at den danske Regjerings Herredømme var suspenderet .... men binde sig for alle kommende 
Tider og under alle Eventualiteter paa denne Maade vilde han ikke, da han ikke kunde indrømme den Enkelte Ret til et saadant Skridt, saalænge ikke en afsluttende Statsact forelaae .... [De andre erklærede sig paa lignende Maade].

Den 6. Juli. [Den fhv. Amtsforvalter Wors a a e, hvis Hustrus Sygdom hindrer en hastig Bortrejse, stilles uden paaviselig Grund under Politiopsyn] .... - Idag have alle vore Hjemmetydskere deres Flag ude, Krandse paa Husene, Blomster og Grønt paa Gaden etc., thi det er deres Herzog Friedrichs Fødselsdag. Paa Slottet vajer ogsaa det trestribede Flag idag for første Gang i denne Krig. [Den prøjs. Overgeneral Prins Carl har dog forbudt yderligere Demonstrationer].

Sønd a g d e n.10.Juli.... Der er kommet den Efterretning her til Byen, at Ministeriet Monrad er afgaaet.

D e n 1 1. J u li. [Justitsr. Worsaae rejst bort fra "vor ulykkelige Egn«, da han dog intet kunde udrette].

D e n 12. J u li. - Den preussiske Pladscommandant, Major v. Baehr af 35. Regiment, har idag ved offentlig opslaaede Placater befalet, at alle danske Indskrifter paa Skilte, Huse, etc. inden tre Dage skulle borttages eller overmales. Næunte Commandant ligger i Quarteer hos Gustav Raben, derfor bliver denne Bestemmelse lettere fork larlig. .... [Dagen derpaa ændres dog Befalingen til et Paabud om ligelydende tysk Tekst vedføjet de danske Indskrifter].

De n 13. J u li. .... - "Apenrader Nachrichten" er glad ved at kunne melde, at den har faaet Befaling til for Fremtiden ikke at optage danske Artikler . .. Som Følge af denne Befaling maatte man tage 
den allerede satte Slutning af Dr. v. Maaks danske Artikel, hvori han søger at oplyse Nordslesvigerne om de Ulykker, de have lidt ved deres Forbindelse med Danmark ...., ud af Bladet, der derfor udkom saa seent. Det er en mærkelig Skjæbnens Ironi, at Doctoren i Indledningen af sin schleswig-holsteinske Sirenesang forsikkrer, at det danske Sprog ikke paa mindste Maade vil blive forurettet i al Følgetid, naar Nordslesvig ogsaa blev skilt fra Danmark. Endnu inden Slutningen af hans Artikel er udkommet, løgnstraffes denne hans Forsikkring.

D e n 1 4. J u li. - [Hele Toldpersonalet faar efter Begæring sin Afsked, da det vægrer sig ved at ændre Uniformerne; Nyudnævnelser]. - Flere østerrigske Saarede ere Vester fra blevne bragte hertil idag. Der tales om et Sammenstød med danske Orlogsfartøjer, formodentlig Kanonbaadene under Capt. H a m m e r. .... [Sikker Efterretning om Ministerskiftet i København]. .... Iblandt vore Hjemmetydskere har Heltzens Udnævnelse til Minister gjort stort Indtryk. Man frygter hans Sag- og Personkundskab, hans Snille og Færdighed i at gribe ind i Begivenhedernes Gang og med Energi at føre sine Planer igjennem, saavidt Muligheden tilsteder. Vi andre glæde os til, at Heltzen er kommen paa en Plads, hvor hans i saa mange Retninger constaterede Duelighed og Aarvaagenhed i denne vanskelige Tid ville være [af] overordentlig Betydning.

Den 17. J u li. [Rygter om dansk Erobring af Barsø. Gentagne, men ubekræftede Forlydender om Vaabenhvile]. - Idag er ogsaa Kirken omsider bleven prydet med den trestribede $K$ lud, som er stukket ud af Glamhullerne over Uhrskiven og dingler Iystelig for den stærke N. V. Vind. 
D e n 1 8. J u li. [Rygtet om et Slag i Nordsøen, hvor Østrigerne har lidt store Tab, holder sig haardnakket].

De n 19. J u li. [Vaabenstilstand Kl. 12 næste Nat. Den ny Amtmand bliver Advokat J ü r g e ns e n, Tønder] .... - Det er ligesom om en Forudfølelse af en Forandring i Situationen begynder at gjøre sig gjældende. De tydske Aviser, vil sige de fra selve Tydskland, lade Yttringer falde, der vinde [d. e. vidne] om Tvivl med Hensyn til, at Krigens endelige Resultat vil fyldestgjøre den tydske Ueberschwängligkeit. Nok pukker og brovter man saa voldsomt som før, men den absolutte Suffisance er ikke mere tilstede. Hvad den schleswigholsteinske Presse angaar, da kjævles Bladene om man skal først oprette Staten Schleswigholstein under Herzog Friedrich og sid en fyldestgjøre Taknemmelighedens Forpligtelser til Preussen, hvilket Flensborger Bladet, Alton. Merkur og flere ville, eller om man $\mathrm{f} ø \mathrm{r} \mathrm{s}$ t skal tilfredsstille Preussens begrundede Fordringer paa Erkjendtlighed, og siden tænke paa Herz. Fr. og hans Rige, som er de Kieler Blades Program. Vor lystelige Byavis er overberuset i Ultraschleswigholsteinisme, og Fuldmanden Traugot t K e pler raisonerer i politisk Delerium tremens saa guddommeligt, som bindegale Folk kun kunne ønske.

Den 21. Ju li. [Mange Vogne med "Plyndregods « fra Jylland]. Den 73-aarige P a u l C la u s e $\mathrm{n}$ (Bødker kaldet) fra Dybvighoved, der i flere Uger har siddet indespærret $i$ et af Fængslerne paa Raadhuset, er idag bleven sat paa fri Fod, uden at have været i Forhør en eneste Gang ....

Den 23. Juli. Vedvarende hele Vognrækker med røvet Gods fra Jylland. Man fortæller at de Sol- 
dater, der udgjøre Bedækningen, underveis drive en indbringende Handel, uanseet at de sælge for meget billige Priser. Parasoler, Gala[n]terivarer, alle Slags have de at offerere.

De n 26. Juli. Efter som man hører har Pastor 0 ls e $n$ i Loyt faaet sin Afsked og, ligesom Degn Mørck sammesteds, tillige Befaling til at forlade Hertugdømmet Slesvig.

De n 27. J u li. Idag fortælles, at Præsterne Roth i Varnæs, Mørk Hansen i Felsted, Feilberg i Ulderup og [en ikke navingiven] ere blevne afskedigede.

D e n 3 0. J u li. [Vaabenhvilen forlænges]. - Om selve Fredsforhandlingerne meddele Bladene saa modsigende Rygter, at det tydeligen fremgaar, at Ingen veed Noget. Igjennem al den Pukken og Brouten, der fylde de tydske Aviser, skimter dog klart Frygten igjennem, at de overspændte Fordringer, nemlig hele Slesvigs fuldstændige Adskillelse fra Danmark, næppe ville være at opnaa.

I Aften modtog jeg en Skrivelse fra Borgemest. Richardi, som underrettede mig om, at Bykollegierne have vedtaget; at jeg til 1 . November skulde fratræde min Bestilling som Regnskabsfører og Kasserer ved Gàsværket.

Søndag den 31. Ju li. [De afskedigede Præster, og Mørk Hansen, afsejlet til København]. - Baron v. Zet litz og den nye slesvigske Commisair v. L e d e r e r, der er kommen i Reverteras Sted, have i Dag været her i Byen og have navnligen havt $S \mathrm{k}$ o levæs enet paa Tapetet. Deres Bestemmelse blev slutteligen den: at Undervisningen i vore offentlige Skoler skulde forblive uforandret som den var og er med dansk Undervisningssprog, og samtlige Skole- 
lærere forblive i deres Embeder. Dog skulde de være forpligtede til at meddele ugentlig 4 Timer Privatunderviisning $\mathrm{i}$ Tydsk mod Betaling.

Den 2. A u gu st. [Den 3 Mdr.s Vaabenstilstand]. Som Fredsbasis angives, at Danmark p ri nc i p i e l t har indrømmet de tre Hertugdømmers Afstaaelse; Ribe Amts Fastlands-Enclaver og Øen Arrø adskilles fra Slesvig, hvorimod de Dele af Vesterhavsøerne, der før laae under Ribe Amt, slaaes til dette.

[Et dansk Orlogsflags Tilsynekomst fremkalder slesvig-holstenske Demonstrationer] .... Af de omtalte politiske Efterretninger havde de udfundet, at Danmark heelt og udeelt havde afstaaet ogsaa Hertugdømmet Slesvig, og Jublen over at dette var opnaaet begyndte alt tidligt om Morgenen. Om Aftenen foranstaltedes et Fakkeltog ned til Prinds Carls Logement, hvor der med Ledsagelse af Militairmusik blev sunget Schleswigholstein etc., og hvor Kepler holdt en stor Tale, hvori han forkyndte, at endelig var Friheden for det danske Tyranni heelt vundet. ... Selve Togets Deeltagere udgjorde rigelig 100 Personer, for allerstørste Deel Haandværkssvende .... men kun faa egentlige Borgere saas deri ....

D e n 3. A u g u s t. - Den stærkt animerede Stemning, vore Hjemmetydskere igaar havde sat sig i, er slappet af $i$ en meget mærkelig Grad. Man begynder at erkjende, at Seierjubelen under alle Omstændigheder var »verfrüht", og at Sagen langtfra var saa afgjort og for Schles. Holst. saa gunstigt afgjort, som de havde indbildt sig selv og Andre, der vilde tro paa. deres Ord og Adfærd. Det iforgaars Eftermiddag til Hovedquarteret ankomne Telegram fra Wien lyder: "Friedenspräliminarien abgeschlossen. Basis: Ab- 
trennung der Herzogthümer. Waffenruhe bis $\mathrm{Ab}$ schluss des Friedens, oder 12 Wochen. Jütland bleibt occupiert." Aviserne som idag ere ankomne, have gydt koldt Vand i det kogende hjemmetydske Blod, der i hiin Depeche havde fundet meget Mere end den indeholder.

Søn dag de n 7. A u gust. ... Ved Middagstid og hen ad Eftermiddagen ankom endeel fra den danske Armee hjempermitterede Slesvigere. Synet af disse Folk har trykket Stemningen iblandt de Dansksindede end mere, da de i denne Permittering saa et Tegn paa, at Slesvig er opgivet. Endnu har man ikke seet Ordlyden af Fredspræliminarierne og svæver derfor imellem Haab og Frygt. Desværre synes Frygten at være mere begrundet end Haabet. ....

De n 8. A u g u st. .... Iaften har jeg da læst Aftrykket af Fredspræliminarierne. Det Haab, som begrundede sig paa Ufuldstændigheden af det til Prinds Carl ankomne Telegram og paa Udtalelser i tydske Blade ...., har svigtet; Aftrædelsen af alle tre Hertugdømmer er skeet uden nogetsomhelst Forbehold!! Slesvig, det danske Sønderjylland, et fra Arilds Tid Danmark tilhørende Land, til hvilket Tydskland ikke har Skin af Retstittel, og $\operatorname{det}[\mathrm{s}]$ troe danske Indvaanere maa drikke den navnløs bittre Skaal, at skulle blive adskilte fra deres Moderland, fra deres Nation, og gaae den nationale Dø̈d imøde! Det vil blive en uhyre trist og sørgelig Tid her, og efter al Sandsynlighed vil Slesvigs Tab over kort eller langt drage Jyllands Tab efter sig, og dermed: Finis Danica! !- dersom ellers ikke Forsynet rækker en frelsende Haand, - Europas ikketydske Magter ville dennesinde ikke. Saa svært straffes paa os Nulevende den danske Regjerings indtil Sløvhed og Fejg- 
hed grændsende Mildhed og Overbærelse imod Oprørspartiet. Havde vor Regjering i Christian VIII['s] Dage kuet dette, - og hvor let kunde det ikke være skeet -, eller havde man efter forrige Oprør fulgt Østerrigs eller Preussens Exempel ligeover for Insurgenterne, saa havde Ilden ikke ulmet saa længe under Asken, indtil den tydske Vind kunde opblæse den store Brand, der nu fortærer vor Velfærd og meget Mere.

De n 10 . A u g u t. [Den ny Pladskommandant, Major Krohn]. Han er en Søn af Generalmajor Krohn, der til sin Tid var dansk Officer, men sluttede sig til Oprøret i 1848 og blev Krigsminister under Insurrectionsregjeringen. Vor nuværende Commandant er en Mand paa noget over de halvtreds, han har været i preussisk Tjeneste i over 30 Aar og stod under det forrige Oprør i Insurgentionerne. Han taler ligesaa godt Dansk som Tydsk, og man siger, at Prinds Carl derfor udtrykkelig har beordret ham hertil. Det lader til, at han er en Mand, der ikke tager synderlige Hensyn [Exempel herpaa] .... Denne Commandantens Fremgangsmaade .... havde bl. a. til Følge følgende interessante lille Episode. En Bonde holdt med sin Vogn for Værtshuusholder Peter Damms Dør i Ramsherred; han havde stort Hastværk; thi hans Kone hjemme laa i Barselseng. .... Men Tilfældet vilde at Commandanten netop i selvsamme Øjeblik skulde gaae forbi og see den forladte Vogn, og som Følge deraf blev Bonden strax stukket i Arrest. [Værtshusholderen søgte imidlertid at gaa i Forbøn for ham, under disse særlige Omstændigheder]. Commandanten spurgte med Strenghed, hvorfor P. Damm talte Dansk, og om han ikke kunde tale Tydsk [hvilket Damm benægtede]. Comman- 
danten spurgte derpaa, om $D$. da var født i Kongeriget, men fik til Svar, at han var født og opdraget i Ulderup i Sundeved, hvor der ikke blev lært Tydsk i Skolerne i hans Ungdom, og at han i de rigelig 20 Aar han havde boet her i Aabenraa ikke havde havt Leilighed til at lære at tale Tydsk. Commandanten lod til at blive lidt forundret over denne Meddelelse [og endnu mere, da Damms Kone, der var født i Varnæs, ikke heller var Tydsk mægtig]. Commandanten spurgte da, hvem der i Damms Hus da forstod og talte med de tydske Soldater, og fik til Svar, at det. gjorde Damms 12-aarige Pigebarn. "Hvor har hun la lært Tydsk?" lød Commandantens Spørgsmaal, og han fik det Svar: "I Skolerne her i Byen." - Denne Samtale gjorde synligt Indtryk paa Commandanten. Han fik derved et fuldstændigt Beviis for, at det tydske Sprog i k k e havde været lært i Sundeveds. Skoler før 1848, men at der ef ter 1848 var bleven givet saadan Undervisning deri i vor Byes Skoler, at et 12aars Pigebarn var istand til at udtrykke sig paa. Tydsk, - hvilket stod i skjærende Modsætning til de Meninger, Commandanten formodentlig har bragt med sig fra Tydskland om de herværende Sprogforhold. Den fængslede Bondemand blev frigivet. -

D e n 11. A u g. - Modet er sunket dybt hos alle Dansksindede .... Jeg har seet Mænd og Quinder med Taarer i Øjne udtalte deres dybe Sjælesmerte over den store Ulykke, og hvormed skal jeg vel trøste dem? Og dog klamre de sig fast til det uvisse Haab, og jevnligen hører jeg udtale som en urokkelig Overbevisning, at det aldrig kan blive ved saaledes, "vi skal nok blive dansk igjen, vi kan aldrig blive tydsk « [og Rygter om bedre Udsigter svirrer]. .. Det ene Rygte, den ene Spaadom efter den anden bli- 
ver gjort til Skamme, men Folket griber med Begjærlighed og usvækket Tillid hvert nyt, der kommer i Omløb. Det er d e t danske H j erte, der banker saa trot og udholdende; skal deres Troskab da kun fore til, at de skulle knuses? - [Men mange taler om at flytte til :Kongeriget.]

Den 12. A ug. [Kommandanten har Bykollegierne hos sig og indprenter dem Lydighed.]

D e n 17. A u g. - Paa Commandantens Befaling ere flere Læs Egegrene bleven kjørte sammen paa Storetorv, hvor en Mængde Soldater ere ifærd med at lave Krandse og Festons deraf, for at bekrandse Husene til imorgen, den østrigske Keisers Fødselsdag. Militæret anbringer Løvprydelserne allevegne, enten Huuseierne synes derom eller ikke [Flag overalt].

D e n 1 8. A u g u st. [Kanonsalut paa Kejserfødselsdagen] - .... det er et mærkeligt Tidens Tegn, at det netop ere preus iske Kanoner, der skulde forkynde det danske Land, at Østerrigs Behersker paa denne Dag for første Gang har seet Verdens Lys. I tidligere Dage have Preussernes Kanoner tidt nok dundret i m o d Østerrigerne, og hvo ved hvor længe eller kort det vil vare, førend det skeer igjen. $-\ldots$ Den første og umiddelbarste Følge af Dagens Højtidelighed er, at min Broders Huus er bleven skammelig ramponeret. De 4 tolvpundige Kanoner stode lige uden for hans Vinduer .... [Ogsaa andre Huse har lidt Overlast].

Den 26. August. [Tysk Ordensuddeling og Soldaterfest]. - Samtlige deputerede Borgere ere i Farten og gaae Huus for Huus med en Petition om atter at faa tydsk Skolesprog indført. ... Hos ud. 
prægede Dansksindede komme de naturligviis ikke, men ellers søge de ind i enhver Familie.

D e n 30 . A u g u s t. - . . . Hen ved Middag viste sig i Taagen ude paa Fjorden et tremastet Fartøj, og da jeg tog Kikkerten, bemærkede jeg istedet for Dannebrog, som jeg havde ventet at see, det p re u ss iske Orlogsflag vaje fra Flagstangen ved Agterstavnen. Altsaa for første Gang sees paa vor Fjord den sorte Ørns og Korses Flag. .... Saa længe vort Havnebassin har existeret har intet andet Orlogsflag. vist sig i det end det danske, og det fremkalder mørke Betragtninger at see Preussernes Krigsørn udfolde sine Vinger der, hvor kun fredelige danske og svenske Flag har vajet. ....

Den ny constituerede Borgmester, en Advokat. G ottburgsen fra Rendsborg, er idag arriveret. hertil.

Den 31. A ugust.... [Borgmester Richardi forlader Byen]. .... Manden var vistnok Schleswigholsteiner, men under hans Ophold og Embedsførelse har han ikke fortrædiget nogen Dansksindede $\mathbf{i}$ mindste Maade. Han skal tværtimod have erklæret, at ikke de Dansksindede, men de Tysksindede vare de Urolige her i Byen, og han havde fundet, at de Mænd, som han havde anseet for at være de fornuftigste, vare netop lige det Modsatte. Man har al Grund til at antage, at han havde for meget Samvittighed .... til at finde sig $i$ det Regimente, vore Hjemmetydskerne har villet have gjennemført, og for hvis Tilveiebringelse de overløb ham uafladelig og stillede de mest extravagante Fordringer. ... - De fem sidste Præster fra Kongeriget: Pastorerne B a y i Kliplev, P a u ls e n i Ensted, $\mathrm{M}$ üh le $\mathrm{n}$ s t e th i Bjolderup, Pa s b jerg i Bedsted og $\mathrm{K}$ i n $\mathbf{c} \mathbf{h}$ i Loyt vare 
idag kaldte op til Amtmanden, der forelagde dem cle Spørgsmaal, som blive gjorte de til Afsættelse og Bortjagning fordømte Embedsmænd, næmlig: om de ved deres Ed til Kong Christian IX ansaae sig for bunden til den danske Regjering? - Svar: Ja! - Om de vilde frigjøre sig for denne Ed? - Svar: Nei, ingen ærlig Mand kunde gjøre sig selv fri for en indgaaet Forpligtelse, end sige for en Ed. - Om de frivilligt vilde nedlægge deres Embeder? Svar: Nei, dertil vare de ikke berettigede. - Efter at disse deres Svar vare blevne tagne til Protocol[s], forlangte de en Udskrift af denne, der blev dem nægtet; de forlangte derfor tilføjet Protocollen, at den af dem begjærede Udskrift var bleven nægtet, hvilket skeete.

De n 5. S e p t. [En dansk Soldaterbegravelse]. Allerede ved tidligere Leiligheder har et talrigt Følge af Byens dansksindede Indvaanere ledsaget afdøde danske Krigeres Liig til Graven, dennesinde var Jordefærden særdeles højtidelig. Et Par Smaapiger paa 12 Aar havde været hos Commandanten og bedet om Lov til at strøe Blomster foran Liigkisten [26 Smaapiger mødte op]. .... Liget blev baaret af preussiske Soldater, foran gik et preussisk Musikcorps, som blæste en Sørgemarch, efter Liget fulgte først de omtalte Piger, derpaa de danske Borgere, siden Commandanten og en talrig Mængde Officerer og dernæst en Militærcommando. I Gaderne .... var der strøet Blomster uden for alle Dansksindedes Huse, og fra Kirkegaardsporten af strøede Smaapigerne Blomster foran Kisten. Pastor Hold t holdt først en meget smuk dansk Tale .... Derpaa henvendte han sig med nogle tyske Ord til det preussiske Militair, idet han fremhævede, at de som Fjender have staaet ligeover for den Afdøde, men nu maatte betragte ham som en 
Kammerad. [Ogsaa de tyske Officerer kaster Jord paa Kisten, og Militærkommanḍoen affyrer 3 Salver over Graven].

De n 6. Sept. - I Formiddags blev den nye tydske Hovedpræst og Provst, en Pastor Gø $\mathrm{t} t \mathrm{i}$ fra Hansühn, i Kirken introduceret i sine nye Embeder. ... Om Aftenen Kl. 6 havde jeg den Ere at gjøre den nye Borgemester Gottburgsens personlige Bekjendtskab. Han kom, ledsaget af en preussisk Militair .... og en Gendarm op paa mit Værelse, tilkjendegav sig .... som Borgermesteren og forlangte Oplysninger angaaende en Adresse, som han vidste, jeg havde havt med at bestille, og som han antog, jeg havde $i$ Huset. Jeg indrømmede strax det første, [indføjet: "sagde Nei til det sidste og "] fortalte ham, at Adressen var en Bøn til Civilautoriteterne i Flensborg om hos Keiseren af Østerrig og Kongen af Preussen at virke hen til, at vi Nordslesvigere kunde forblive ved vort Fædreland Danmark. Der udspandt sig en temmelig heftig Disput imellem Herr Borgermesteren og mig, baade med Hensyn til Adressens Loyalitet, som jeg paastod og som han benægtede, og ... min Deelagtighed i den. Hans Udtalelser vidnede om, at han fuldstændig havde Følelsen om at være i Besiddelse af Magten. .... Jevnligen truede han mig med Arrestering og Overgivelse til Militairauroriteternes Strenghed. .... Hele Samtalen blev selvfølgelig kun ført [paa] Tydsk, og der blev Intet Skriftligt foretaget. - En halv Time efter, at alle Tre vare gaaede bort, kom Overjægeren atter løbende .... og erklærede, at han ifølge Commandantens Ordre skulde forblive hos mig og bevogte mig. Han aflaasede den anden Indgangsdør til min Bolig og tog Nøglen til sig, og var i det Hele meget nidkjær og studs i sin Tjeneste. [Se- 
nere Afløsning, Kl. 9 Frigivelse]. En lignende Bèhandling erfarede ogsaa M. Bahnsen samme Aften .... Bahnsen udsagde, at han var den der alene havde paataget sig at faa den [Adressen] udbredt, og at de indkomne Exemplarer vare afsendte. Videre Forklaring .... væ vrede han sig ved at afgive, idet han erklærede at ville paatage sig hele Ansvaret. Hos ham var Borgermesteren forresten høflig og artig, og talte Dansk. Ogsaa B. fik Stuearrest til Kl. $8^{1 / 2} \ldots$

De n 7. S e p t. - I Formiddags var M. Bahnsen atter $\mathrm{i}$ Forhør hos Borgermesteren ang. Adressen; han gjentog sine Udsagn fra Aftenen tilforn.

De n 10. S ept. - Som Bahnsen fortæller mig, blev han ig a a r Aftes $\mathrm{Kl}$. henimod $11 \ldots$ banket op af 3 Gendarmer, af hvilke den Ene anmodede ham om at levere dem den Adresse, som var bleven ham bragt af [en] Karl fra Callesens Teglværk. B. vidste ingen Adresse om, da han ingen havde modtaget efter at have været i Forhør hos Borgermesteren. Gendarmen holdt sig til Tjenestekarlens Udsagn [men gik, da Bahnsens. Kone erklærede at have brændt vedk. Adresse].

Om Aftenen Kl. 6 er M. Bahnsen bleven indsat i et af Raadhusets Arrester, af hvad Grund vides ikke. [Efter Sigende har han Forplejning fra sit Hjem].

Søndag den 11. Sept. - En Deputation, bestaaende af $\mathrm{Middelheus,} \mathrm{D.} \mathrm{Dam} \mathrm{m}$, C. C. F ischer, N. Sørensen og N. Elberg, har i Formiddags været hos Commandanten, og bad om at frigive Bahnsen af Fængslet imod hvad som helst Kaution være skulde, men Commandanten, en Major v. Un $\mathbf{r u h}$, svarede bestemt benægtende. Ogsaa Bønnen om at forflytte Bahnsen fra Tyvefængslet til et bedre Værelse nægtede [han] at opfylde, tilføjende, at 
B. selv var Skyld i sin Arrestering, da han ikke vilde navngive fra hvem han havde faaet de Adresser, der vare Anledning til hele Fremgangsmaaden; han (Commandanten) vilde inden 8 Dage være fuldstændig kjendt med den nøjeste Detail af Sagen, og da han var her for at holde Orden og Rolighed, kunde han umulig tilstede, at Adresser, som .... ligefrem vare forbudne [iflg.] Feltmarskalk Wrangels Proclamation, circulerede. Paa en Bemærkning, at Civilcommissairerne alt i Marts havde opfordret dansksindede Borgere her af Byen til uden Betænkning at henvende. sig til dem med Adresser, svarede Commandanten: Det var i Marts, men nu ere vi i September. [Heller ikke hos Prins Friedrich Carl opnaaede man noget].

[Et Officersbal; blandt Dekorationerne ogsaa det. danske Flag]. - Om dette Bal erfaredes senere, at. ikke en eneste Dansksindet Familie havde taget imod Indbydelsen, og at i k k e e n e ne s t e dansk Dame havde været tilstede paa Ballet. Det. store Udfald af Damer, som derved maatte opstaae, søgte man at udfylde ved at give Gustav Raben Fuldmagt til at indbyde alle de af det smukke Kjøn, som han syntes var Eren værdig. En østerrigsk Officer yttrede efter Ballet sin Beundring af den Heroisme, hvormed saa mange "grauhalsige Heldinnen vom vorigen Feldzuge« ubevægeligen havde holdt ud i deres vacante Stilling, som Ingen viste Lyst til at udfrie dem af. - Som jeg senere hørte er en Deputation fra Haderslev om Aftenen kommen her igjennem, for at bringe den Adresse, der her har fremkaldt saa stor Mudder, til Civilcommissairerne. Capt. N. Elberg sluttede sig til den med Adresserne for vor By og Omegn.

[Den 12. Sept. og flg. Dage Oplysninger om Lettel- 
ser i Indkvarteringsbyrden. Prins Friedrich Carl af Preussen og en stor Del af Officersstaben afrejst.]

D e n 15. S e p t. - Idag er paa Gadehjørnerne opslaaet og i "Ap. Nachrichten" offentliggjort følgende: "Erlass Nr. 5 II Q. Apenrade 10. Sept. 1864. Es ist einerseits zur Kenntniss gekommen, dass vom Auslande her Petitionen zur Unterschrift verbreitet werden, und dass sich Bewohner des Herzogthums Schlesvig an der Verbreitung dieser Petitionen betheiligt, und Unterschriften zu denselben gesammelt haben. Es diene denselben zur Kenntniss, dass der Kriegszustand augenblicklich noch besteht, und dass das Verbreiten derartiger Petitionen und das Sammeln von Unterschriften nach der Strenge der Kriegsgesetze unnachsichtlich bestraft werden wird.«

Von Seiten des Ober-Commandos

Der Ober-Quartiermeister

gez. v. Podbielski, Oberst.

D e n 17. S e p t. [M. Bahnsen omsider frigivet] ... Under sin Arrestering har B. gjentagne Gange været i Forhør. I Førstningen undslog han sig for at give bestemte Erklæringer om, hvorfra han havde faaet Adresserne, da han frygtede for, at dette kunde lede til, at de bleve opsnappede og saaledes hele Planen forstyrret. Men efterat han havde erfaret, at de vare blevne overrakte til Civilcommissairerne, udsagde han i Forhøret, at han .... vilde meddele Alt, hvad han vidste om den, og gjorde dette. Men Commandanten, Major v. Un r u h, der selv var tilstede, lod ham nu vide, at .... hans forskjellige og afvigende Udsagn havde fremkaldt den Mening, at han havde faaet den fra Kjøbenhavn; derfor vilde han nu give ham 24 Timers Betænkningstid; indrømmede han da. ikke Sandheden, vilde hans Seng blive ham fratagen 
og than hensat i 3 Døgn paa Vand og Brød. Saa atter 24 Timers Betænketid [og igen Vand og Brød osv. indtil Bekendelsen forelaa]. Ordren til hans Frigivelse indtraf imidlertid inden denne Procedure blev iværksat imod den 56-aarige Stænderdeputeret.

Den 24. September. - Imorges har Provst Gøttig aflagt et Besøg i Jomfru D r e s e n s Pigeskole. Han holdt et meget indtrængende Foredrag til Eleverne angaaende den Lærebog i Verdenshistorie, der hidtil var bleven brugt der i Skolen, hvilken Bog han skildrede som særdeles utilladelig, da den let kunde bringe Børnene paa den Tanke, at de vare Danske og hørte til Danmark, hvilket slet ikke var Tilfældet; de vare Slesvigere, hørte til Schleswigholstein og længere Sydpaa til Tydskland, hvad den omtalte Lærebog yttrede om, at der i 1848—49 var skeet Oprør, var aldeles usandt; Schleswigholsteinerne vare ingen Wühlere, ingen Insurgenter eller Oprørere, de havde fuldkommen Ret, men de Danske havde den største Uret. [Præsten beslaglagde efter Foredraget en Række Ekspl, af Lærebogen].

Den 11. O ctober. [Fra 27. Sept. til 10. Okt. intet]. Efter at Byens Indvaanere igaar uventet vare blevne tilsagde til idag at møde paa Raadhuset, for at afstemme om Skolesproget skulde være Dansk el ler Tydsk, fandt denne Afstemning Sted fra Kl. 81/4. ... Tilsigelsen skete for Byen af de deputerede Borgere, i Landsognet af Gensdarmer [til Dels saa sent, at de Indbudte vanskeligt kunde møde rettidigt]. I Raadhussalen gik Afstemningen for sig. Ved den anden Væg stod et Bord, bag hvilket Amtmand Jürgensen, Borgemester Gottburgsen og Provst Gøttig toge Plads, endvidere Raadmændene Jensen, Raben og Ahlmann og de deputerede Borgere. Efterhaan- 
den indfandt sig de Indbudte, der mødte bl. a. et betydeligt Antal tydske Quindeligheder, mens kun enkelte danske Fruentimmer havde indfundet sig. Kl. $8^{1 / 4}$ aabnede Amtmanden Mødet med en tydsk Tale: Da alt tidligere en Petition fra Medlemmer af Skolecommunen var bleven indgiven til Skolecommissairerne, og deri bedet om Indførelsen af tydsk Skolesprog, saaledes som det havde bestaaet indtil 1850, saa havde Civilcommissairerne paalagt Skolecollegiet at lade foretage en almindelig Afstemning, for "glaubwürdig" at constatere, hvad der var Ønske for Flertallet af Byens Indvaanere. .... Enhver skulde afgive.sin Stemme, om han ønskede at beholde det danske Skolesprog som det bestod siden 1850, eller det tydske som det havde existeret førend nævnte Aar; men man maatte jo ikke ansee denne Afstemning som en politisk Demonstration, den stod tvertimod saa fjern fra al politisk Væsen, at en Dansksindet gjerne kunde stemme for det tydske Skolesprog .... og omvendt en Tydsksindet for det danske; men der laa dog en høj Betydning i Afstemningen; thi den vilde afgjøre om vore Børn skulde blive deelagtige $\mathbf{i}$ »deutsche Kultur und Gesittung " eller ikke. [Der skulde dog i alle Tilfælde gives enkelte Timer i det ikke-foretrukne Sprog]. - Da det tydske Foredrag var endt, recapitulerede Amtmanden dets væsentligste Indhold paa Dansk, ved hvilken Leilighed han .... sagde de højst mærkelige Ord: "Der vil blive givet Undervisning i det danske Sprog, det vil sige i det danske Skriftsprog, thi den danske Dialect læres paa Gaden," - en naiv og aabenhjertet Tilstaaelse om hvad Folkesproget er, netop i det Øjeblik, da der foranstaltes en Afstemning om hvad Skolesproget skal være, som om det burde være et 
andet end Skolesproget. [Borgmesteren tilkendegiver derefter, at hver enkelt foran Valgbordet skal udtale et "Dänisch" eller "Deutsch«]. Derpaa begyndte Afstemningen og fremmedes meget rask, da ingen oplæsning af hvert enkelt Votum fandt Sted, altsaa eiheller nogen Controlle var tilstede. Det endelige Resultat faldt saaledes ud, at $\mathbf{4 1 2}$ stemte for tydsk Undervisningssprog, 264 for dansk. At det ikke kunde komme anderledes var let at forudsee. Tydskerne have uden al Tvivl i Forvejen været underrettet .... De mødte saa godt som Alle, og da Afstemningen var skreden noget frem, bleve Koner og Enker af de deputerede Borgere hentede fra alle Byens Kanter .... De Danske derimod vare ved den pludselige Indbydelse blevne fuldstændig overraskede, og Mangfoldige af dem udebleve .... Tidens Tryk og de mislige Forhold, der fra alle Sider truer dem, gjorde sig gjældende paa en forklarlig Maade. [Flere besynderlige Forhold paatales; Tyskerne favoriseredes uforsvarligt.]

Den $12.0 \mathrm{ctb}$. - I Eftermiddag vare Boghandler $N$. $N ø r$ en s e $n$ og hans Søn Ri c hard indstævnede for Retten i Anledning af den af Skræddersvend De lf s paa Mødet igaar afgivne Sigtelse. Det er en ganske eiendommelig Maade at indstævne en Borgermand til Forhør, fordi en Landstryger, aabenbart for at tjene et politisk Parti, udtaler en Beskyldning, der forresten er aldeles blottet for Grund. Da Sørensen begyndte at tale Dansk, anmodede Borgemesteren ham høfligst om at tale Tydsk, eftersom Protocollen blev ført paa Tydsk. [Sørensen indvilger heri, men bestrider bestemt Paastanden om, at han ved Bestikkelse skulde have forsøgt at hverve Stemmer for d a n sk Skolesprog]. S. yttrede ... $\sin$ store 
Forundring over, at Scenen paa Afstemningsdagen var bleven taalt, og bemærkede, at en saadan Scandale aldrig var forefalden, da vi havde danske Embedsmænd ...., at "ein so schoflicher Mensch offentlig fornærmede en respectabel Borger paa en saadan Maade. .... [Sørensen ønskede tilført Protokollen, at han krævede Ophavsmanden til Skandalen straffet efter Lovens Strenghed. Borgmesteren paalægger ham at tie om Sagen!] .... Siden kom hans Søn i Forhør, men demitteredes ligeledes uden mindste Resultat ....

De $n$ 31. Octb. - Ved Middagstid begyndte de trefarvede Flag at komme tilsyne, og hen paa Eftermiddagen vare alle Rettroendes Huse prydede med den hjemmetydske Tricolor; man havde faaet Melding om at Freden var underskreven.

Den 5. N ovemb. - Idag mærke vi her den første større Bevægelse af de preussiske Tropper i definitiv sydlig Retning ....

Søndagen d en 6. Nove mb. [Storm og Højvande] .... Uden for Sønderport stod Vandet højt over Gaden og ind i flere Huse. .... Paa Skibsbroen stod det lige op til Fortouget for Agent Fischers Huus, gik ind i Jacobsens lange Bygning ved Bækken for Enden af Gildegaden, oversvømmede hele Madestien og naaede op i Haverne. ... Paa Skibsbroen stod Vandet 7 Tommer under Højvandemærket fra 1837. Diget foran Kiil blev inde paa Nørrebro gjennembrudt af Havet, der ogsaa steeg over Diget fra Skibsbroen til Lensnakke og som et Vandfald styrtede ned $i$ de lave Enge. .... Ligeledes løb det over i Slotsgraven, og hele Alleen ud til Hjelm stod under Vand.

Den 14 . N ove m b. .... Afvigte Nat er der fore- 
faldet blodige Slagsmaal paa Gaden imellem Civile og Soldater. [To Farversvende blev alvorligt saarede af Sabelhug].

D e n 15 . N o v. - Det er idag et Aar siden K o n g Frederik VII lukkede sine Øjne!!

Den 16. Nov. - Det er Aarsdagen for Udstedelsen af den Proclamation, hvormed Schlesvigholsteinernes Herzog Friedrich forkyndte Verden sin Regjeringstiltrædelse. [Hjemmetysk Flagning og Illumination paa et enkelt Hotel om Aftenen].

De n 21 . N o v. .... Der hersker i Byen den største militairske Bevægelse, idet en endeløs Masse af alle Slags Kjøretøjer og Soldater af de forskjelligste Vaabenarter fylder Gaderne.

Idag bragte "Berlingske Tidende" tre Proclamationer fra Kong Christian IX af $16 \mathrm{de}$ ds. I den ene løser han Undersaatterne og Embedsmændene i de afstaaede Landsdele fra deres Troskabs- og Embedsed.

D e n 23. Nov. [Den fortsatte Troppebevægelse Syd paa]. - Et preuss. Cuiraseer Regiment rykkede ind under Musikken "Den tapre Landsoldat"...

D e n 28. N o ve m b. .... - Ved Middag kommer min Soldat og beretter, at Tropperne om et par Timer alle skulle marchere til Rendsborg, da Hannoveranerne og Sachserne i Holsten skulle børstes. - Hamborger Posten er udeblevet.

De n 30 . Nov. .... Hermed ere saa godt som alle de tydske Tropper, der have ligget Nord for os, komne tilbage. Den herværende Besætning er, paa et ubetydeligt Mandskab nær, ogsaa afmarcheret, Skilderhusene staae forladt, og Borgernes Huse [ere] for allerstørste Parten blevne befriede for Indquartering. 
De n 3. De c b r. - I de sidste Dage have endeeI. løse Rygter om Preussernes Sammenstød med Forbundstropperne i Holsten været i Omløb. Landboere forsikkrer, at de tydeligt have hørt hyppige Kanonskud i sydlig Retning. [Avisernes Beretninger viser dog, at Rejsendes Fortællinger ikke er at lide paa.] Om Aftenen blev der ringet med Kirkeklokkerne en heel Time, for at indlede den Takkefest, som ifølge højere Befaling imorgen skal afholdes i alle Landets Kirker for Fredens Opnaaelse.

$\mathrm{D}$ e $n$ 9. De $\mathrm{cb}$. - Jeg opholder mig siden igaar Aftes hos min Fætter C. Calls e n paa Teglværket, i hvis herlige Familiekreds jeg er som hjemme, og agter at forblive $i$ nogle Dage.

Søn dag den 11. De c b. - I Eftermiddags gjorde jeg med Calisen en Tur til Petersen i Hostrup. Der fortaltes der os, at der for en otte Dages Tid siden havde været Dands i Felsted Kro for Tjenestetyende og andre unge Folk. En Gendarm, som indfandt sig til Gildet, blev behandlet paa en saa uvenlig Maade, at han reed over til Hostrup og hentede sin Collega, og begge i Forening søgte nu at haandhæve tydsk Orden i Dandsestuen. .... Derved blev Stemningen meer og meer forbittret, det kom til Skjældsord og Haandgribeligheder; Gendarmerne ryddede nu Localet, men udenfor stimlede de Uddrevne sammen. Der blev kastet med Steen paa Gendarmerne, og den ene af dem affyrede 2 skud med sin Revolver efter en Karl, dog uden at tilføje ham nogen Skade. Dagen efter beordredes Deeltagerne i Gildet til Graasteen, og 8 af dem bleve idømte 3 Dages Fængsel paa Vand og Brød....

De n 14. D e c. - Idag kom den Troppeafdeling 
her til Byen, som indtil Videre skal ligge i Garnison. .... Commandant er en Major C ra n a $\mathrm{ch}$....

Søndag d e n 18. De c b. - Igaar Aftes og inat er af de preussiske Lazarettetjenere og Trainsoldater udøvet diverse Excesser. Hos Gjæstgiver P. Damm begyndte de alt Kl. 8 at gjøre Scandale, itusloge Flasker og Glas, sønderbrøde Stole og mishandlede saa vel Værten som nogle Tilstedeværende med Slag. [Een fik et Sabelhug i Hovedet]. Politibetjent Gielow blev hentet, og da han ikke kunde holde Styr, hentede han en Patrouille fra Vagten, men denne lod Urostifterne undløbe.... [Man gik nu til Borgmesteren, som beroligede Damm] .... Men Kl. 11 fik Damm først et Vindue slaaet ind, længere ud paa Natten alle de øvrige Vinduer, inclusive Sprosserne. Borgmesteren blev nu banket op og siden ogsaa Commandanten. Soldaterne bleve beordrede op paa Kirkegaarden, og P. Damm udpegede nogle af Skandalemagerne. .... Der blev ham sagt, at Folkene skulde blive afstraffede, naar de kom til Berlin. Allerede to Gange før have de selvsamme preussiske Militair[e] huseret paa lignende Maade hos ham....

D e n 20. De c. - Som man hører er istedet for den afdøde Lüders Købmand $H$ of $f g$ a $r$ d bleven valgt til Raadmand af Magistratens øvrige Medlemmer. Det har sat ondt Blod, at Mænd, der have fungeret som Deputerede i flere Aar (før 1848) ere blevne forbigaaede ....; men Kronjyden Hoffgaard er en mageløs Dänenfresser og en villig Appendix til Gustav Ravn, der er Sjælen i hele Offentligheden nutiltids.

D e n 2 8. D e c. - Et dybt Indtryk paa Alle, saaveI Byens Folk som Landboere, Tydsksindede saavelsom Dansksindede, gjør den Behandling, de unge nyan- 
komne preussiske Menige ved Excerceringen maae tage imod af Underofficererne. De Menige ere fra Rhinprovindserne, Underofficererne derimod Brandenborgere, og Sidstnævnte uddeele under Vaabenøvelserne ikke alene de fæleste Skjændsord, saasom Schweinehund, Esel, Schafskopf etc. for den allermindste Forseelse, men regalere dem af Soldaterne, der ikke hurtigt nok kunne fatte Excercitsen, med Puf og Stød, Ørefigen med knyttet Næve, Slag i Nakken med ditto, ja i Næse og Mund, saa Blodet flyder; selv de brutaleste Fodspark for Maven etc. blive ikke sparede. Man ser sig i Speil herpaa og tænker paa sine egne Børn.

D e $n 30$. D e c. - Da det er Aarsdagen for Dolzigerens Ankomst til Holsten .... have hans Tilhængere opstillet et par Tjæretønder paa Galgebjerg, Lensnakke etc., som der om Aftenen blev tændt Ild i. Det fattige Foretagende ændsedes af Ingen, kun nogle enkelte Stammverwandte afsang paa Galgebjerg deres Vise til Morskab for en Flok Drenge, der lo dem ud. Flagningen om Dagen var yderst tarvelig, det synes som om de augustenborgske Aktier dale svært.

\section{Noter.}

1/1: Ministeriet Monrad blev dannet ${ }^{31 / 12} 1863$.

${ }^{31} / 1$ : Prøjsernes Fremrykning fandt dog først Sted den 1. Febr.

1/2: "Dannevirke« har bl. a. Overskriften: „Tydskernes første alvorlige Sammenstød med de Danske er blevet kronet med Seir for os." -

$\%$ : Rømningen skete som bekendt Natten mellem d. 5. og 6. Febr.

${ }^{10}$ 2: : Gusta y Raben, Skibsreder, ivrig Slesvigholstener, derfor Genstand for Fischers stadige Opmærksomhed, ogsaa i de følgende Aar. Se især $1 / 5,3 / 5,21 / 5,{ }^{6} / 8,7 / 8,23 / 6,12 / 7,{ }_{11 / 8} 1864$ (Dagb.) 
11/2: Bystyrelsen var i Hænderne paa $M$ a $g$ is traten og et Deputeretkollegi m.

I Spidsen for Magistraten stod Amtmand, Kammerherre E. S. E. H eltzen (der var Overøvighed for Købstæderne Aabenraa, Sønderborg og Frøskøbing), samt Borgmester og Byfoged, Justitsraad P. J. E. L u n n. Desuden sad i Magistraten de 4 Raadmænd: Agent J. $H$. Middelheus, Martin Bahnsen, Detlef Dam og Agent Christopher Conrad Fis cher. Om sidstnæunte, Fr. F.s Broder, se Sønderj. Aarb. 1924, S. 168 f. Deputeretkollegiet bestod af 12 Medlemmer.

13/2: Kmhr. Heltzen, fra 1850 Amtmand i Aabenraa, iøvrigt dansk Politiker, Helstatstilhænger, Juli 1864 Minister, men styrtet Jan. 1865, idet han - med tvivlsom Ret - blev mistænkt for Enevældetendenser. Se især ${ }^{15} / 5,{ }^{28} / 5,{ }^{28} / 6, \quad 0 g$ ${ }^{14}, 7$ i Dagb.

16/2-18/2: Géneral Wrangel vaklede $i$ sin Beslutning, før han overskred Grænsen til Kongeriget. Østrig ønskede, at man foreløbig kun skulde holde Slesvig besat.

22/2: Købmand Hof f a a r d, skønt Kronjyde af Fødsel en af Tyskhedens fremtrædende Mænd, senere Deputeret og Raadmand. (Se $1 / 6$ og $20 / 12$ ).

18/s: Der faldt d. 15de enkelte Granater i Sønderborg.

18/s: I de haarde Dybbølkampe 17.-18. Marts var de danske Tab langt de største.

${ }^{2 \mathrm{R}}$ 2... $^{29} / 3$ : Dybbølforsvaret havde en heldig Dag d. 28de.

${ }^{30} \%$ : Kmhr. Chr. H. Mølle r, Skovg a a rd, Stænderdeputeret for Aabenraa Landdistrikter.

8/4: Borgm. L un $n$ (se ovenfor). - Kancelliraad B l um e var Herredsfoged for Ris og Sdr. Rangstrup, men boede ved Aabenraa.

15/4: Om Borgm. R i c h ard i se endvidere ${ }_{1 / 6}^{1 / 6}$ og den smukke Anerkendelse af hans Loyalitet i Dagbogen $31 / 8$.

16/4: M. B a h n s e n, Raadmand og Stænderdeputeret, valgt for Aabenraa By. Han var af gl. Købmandsslægt, opr. Sømand, senere Farver, drev ogsaa historiske og naturvidenskabelige Studier. Han var Fischers jævnaldrende og til sin Død (1875) bosat i Aabenraa (Biograf. Lex., "Haabets Mænd « S, $53 \mathrm{ff}$.). Se især ${ }^{26} / 5,6 / 9$ o. flg. Dage.

18/4: Beskydningen ophørte i Virkeligheden Kl. 10 , hvorefter Skanserne blev stormet.

22/4: Kommissær H u n d ew ad t og Købma. Herm. Davidsen blev senere begge Medlemmer af Deputeretkollegiet $(1 / 6)$.

30/4: Fredericia blev rømmet allerede d. 28. April, men først Dagen efter rykkede Østrigerne ind.

1/5: Havnefoged C. C. F is cher, se Sønderj. Aarb. 1924, S. $168 \mathrm{ff}$, (jfr. Noten ${ }^{11 / 2}$ ). 
3/s: M a r c. H. Lü ders (»unser Lüders»), se især 8/5. Han døde iøvrigt senere paa Aaret, som Raadmand afløst af Kbmd. Hoffgaard.

14/5: B. P. G o d t, Præst i Rinkenas 1842-45, i Felsted 1846-51, Generalsuperintendent $1864-85$. Se $16 / 5,28 / 5$ i Dagb.

15/s: Nik. Laurentius F e i l berg (1806-99), Præst i Ullerup (1847-64), Folkloristen H. F. Feilbergs Fader. I en Række Breve fra Krigen 1864 (offentliggjort i "Museum" 1890) belyser han Tilstandene i Sundeved. Visitatsen er omtalt i et Brev af $14 / 5$ (anf. Sted S. 253). Kirkeværgerne va $r$ til Stede, men Forældre og Børn udeblev. - Ligeledes refererer Feilberg Samtalen med Provst Godt ang. sin Stilling til tidligere og nuværende Magthavere, hvor han vil skelne skarpt mellem Oprør og "Krigens Ret« (»Museum« 1890, S. 254). Se om N. L. F. Sønderj. Aarb. 1927.

18/5: Om de kirkelige Forhold under Krigen fortæller ogsaa H. F. F e i l b e r g, der 1864 var Præst i Store Vi. Se Sønderj. Aarb. 1895 og 1923.

21/5: Kobmd. F. A. J ens en blev senere Medlem af Deputeretkollegiet (se $1 / 6$ ).

27/5: Friherre v. Z e d litz (1840-1919), fl'a Febr. 1864 ligesom Østrigeren R e v e t e r a slesvigsk Civilkommissær. Hans Virksomhed fortsattes i Manteuffels Periode 1865-66 og gav ofte Anledning til Omtale i Fischers Dagbøger fra disse Aar. Se $27{ }_{28} / 6$ og $31 / 7$ i Dagb. 64 .

1/6: "Bürgerverein« er den tyskpatriotiske Forening som "Frederiksklubben" den danske.

21/6: "Apenrader Nachrichten", se ogsaa ${ }^{13 / 7}$ og $18 / 7 \mathrm{i}$ Dagb.

25/6: Prins C a rl af Hohenzollern, den senere Carol I af Rumænien (1866-1914).

27/8: M. Mø r k H a n s e n, (1815-95), Præst i Felsted 1850-64; 1861 Stænderdeputeret. Som de fleste dansksindede Præster blev han forvist i Juli 1864, men satte længe sit Haab til en mulig Tilbagevenden. Først 1866 tog han Præsteembede i Vonsild-Dalby. Om hans nationalpolitiske Gerning se H. Kau: M. Mørk Hansen og den danske Sag i Sønderjylland (1899).

$2 \%$ : Johs. Andr. R e h h of f $(1800-83), 1848$ af den provisoriske Regering indsat som Superintendent for den danske Del af Slesvig, 1850 afskediget af den danske Regering, da han søgte at hindre Genindsættelsen af danske Præster. 1864 afslog han dog Tilbudet om at blive Generalsuperintendent for Slesvig.

Jac. Hansen Hol d t, Kompastor i Aabenraa 1851-65. Se ogsaa 5/9 (Dagb.).

10/7: Ministeriet Monrad traadte tilbage d. 8. Juli.

14/7: Kaptajnløjtnant $\mathrm{H}$ a $\mathrm{mm}$ e $\mathrm{r}$ havde den 12. Juli tilbageslaaet et østrigsk Angreb paa Før, men maatte faa Dage senere give op. 
He 1 t z e n blev Justits- og foreløbig Kultusminister i Ministeriet Bluhme.

10/7: Amtmand J ürgensen, se ogsaa 11/10 i Dagb. Traugott Kepler, Redaktør af det tyske Aabenraablad.

30/8: Borgmester G o t t b u rg s e n, se $\%$ o. flg. i Dagb.

$\%$ : Pastor F. G. Gø t i g, f. i Flensborg 1813, Præst i Aabenraa 1864-92. Se Dagb. ${ }^{24} / 8$.

11/9: Middelheus, Damm og C. C. Fischer var M. Bahnsens tidligere Medsenatorer (se Noten 11/2). $\mathrm{Nic.} \mathrm{S} ø \mathbf{r e n s e n , F r . ~ F i s c h e r s ~ S v o g e r , ~ s i d e n ~}$ 1859 Udgiver af $» F r e i a \ll . ~-~ S e ~ D a g b . ~{ }^{12} / 10$.

${ }^{24} / 8,11 / 10$ : Ogsaa for de flg. Aar giver Dagbøgerne ret udførlige Bidrag til Belysning af Skole- og Kirkeforhold.

\%/12: Fætteren C. C a lls en, Possekær, senere Medlem af Provinslanddagen.

11/12: B. P e terse n, Hostrup, Fischers nære Ven, ligesom Callsen en af Danskhedens førende Personligheder paa Aabenraaegnen.

30/12: Hertug Fried ri ch (VIII) af Augustenborg, opholdt sig mellem Krigene især paa sit Gods "Dolzig" i Posen. 